Scientific paper

\title{
The Synthesis of Diquinone and Dihydroquinone Derivatives of Calix[4]arene and Electrochemical Characterization on Au(111) surface
}

\author{
Boštjan Genorio \\ University of Ljubljana, Faculty of Chemistry and Chemical Technology, Večna pot 113, 1000 Ljubljana, Slovenia \\ *Corresponding author: E-mail: bostjan.genorio@fkkt.uni-lj.si \\ Tel: +38614798586
}

Received: 25-01-2016

\begin{abstract}
In the memory of Janez (Janko) Jamnik, my doctoral advisor who taught me that everything can be done and built if there is a vision and $a$ will.
\end{abstract}

\begin{abstract}
Several new electroactive diquinone and dihydroquinone derivatives of calix[4]arene bearing anchor functional groups were designed, synthesized and characterized. A method for selective protection of the hydroquinone -OH groups with trimethylsilyl groups (TMS) either on lower-rim or on upper-rim was developed. Four selected molecules - with sulfide anchor groups and carboxylic anchor groups - were adsorbed onto Au(111) single crystal surface using ex-situ and insitu self-assembly methods. Adsorbed molecules were then electrochemically probed with cyclic voltammetry. All adsorbed molecules showed redox response which changed during cycling. After conditioning CVs stabilized and showed two distinct current peaks for all molecules. Synthesized and electrochemically probed molecules are of interest to: Li-ion batteries (as cathode materials and overcharge protection), beyond Li-ion batteries and redox-flow batteries.
\end{abstract}

Keywords: Electroactive molecules, calixarene, quinone, hydroquinone, electrochemistry

\section{Introduction}

World energy consumption is continuously growing with electrical energy being the single largest consumer. Today roughly $68 \%$ of electrical energy is generated from the fossil fuels. ${ }^{1}$ It is predicted that consumption of electrical energy will double in the next 30 years. Considering the limited natural resources and the environmental impact of the fossil fuels and its combustion products, the alternative sources of electrical energy together with electrochemical energy storage should be taken into account. Batteries, being the main representative of electrochemical energy storage, will play a key role in the future energy consumption cycle.

Over the past decades a tremendous work has been done on the field of the batteries. In particular, Li-ion batteries experienced the biggest boom among them, due to high specific energy (energy per unit weight) and high energy density (energy per unit volume). ${ }^{2}$ However, recently the research was being diverted to the other battery chemistries too, in order to increase energy density and decrease the cost of the final product. ${ }^{3}$ One of the revived fields is the use of redox active organic molecules in the battery systems. Advantages of the redox active organic molecules are low cost, high specific capacity, abundance, flexibility, safety, recyclability and sustainability. Up to date, redox active organic molecules were used as: redox shuttles in Li-ion batteries, ${ }^{4}$ active cathode materials, ${ }^{5,6}$ and active anode materials. ${ }^{7}$ Depending on the nature of the system, redox active organic molecules can be: a) dissolved in the organic solvents - redox shuttles and redox-flow batteries ${ }^{8,9}$ b) grafted to the solid support - solid cathode in Li-ion batteries, ${ }^{10-13}$ or c) free standing cathode material. ${ }^{14}$ Redox active organic molecules are chemically divided into: ${ }^{6}$ organosulfur molecules, ${ }^{15}$ organic free radical compounds, ${ }^{16}$ and carbonyl compounds. ${ }^{17}$ The latter, having a quinone/hydroquinone as a key representative, are playing a significant role in electroactivity relevant to biochemistry, medicine and electrochemistry. Quinone derivatives were tested as cathode materials in Li-ion batteries ${ }^{10-12,18}$ and redox-flow batteries. ${ }^{19}$ Although it was demonstrated that quinones are promising candidates for 
the use in energy storage, the field is still in its infancy. Motivated by above mentioned and the fact that there is a lack of fundamental understanding, we have focused on design of new quinone derivatives and electrochemical characterization.

In the present study, we examined several synthetic routes in order to synthesize quinone derivatives of calix[4]arene which could be then bound to the electrode materials and electrochemically tested. Calix[4]arene, ${ }^{20}$ which was used as starting compound, is in particularly interesting for electrochemical applications, due to inherently opened cavities in the macrocycle. Cavities are potential sites for sieving cations with small ionic radius such as $\mathrm{H}^{+}$or $\mathrm{Li}^{+}{ }^{21-23}$ The letter is relevant to the enhanced accessibility of the active species in the energy conversion and storage systems. The crucial step in synthetic routes was the introduction of anchor functional groups. We have introduced carboxylic and sulfur containing anchor functional group. The latter is advantageous due to strong sulfur - noble metal interaction. Both, "short" anchors where redox active center would be close to the electrode surface and "long" anchors where center is further away from the electrode surface were introduced. By variation of the length we were hoping to investigate electrochemical reaction mechanisms. Successfully synthesized organic molecules were then anchored to the $\mathrm{Au}(111)$ single crystal surface using self-assembly proto$\mathrm{col}^{24}$ and electrochemically probed.

\section{Results and Discussion}

The synthesis scheme is summarized in the Scheme 1. In the first attempt we have tried to introduce "short" sulfur based functional groups to the upper rim of the calix[4]arene macrocycle. We hypothesized that using "short" functional groups would bring electroactive centers of the molecule closer to the electrode material and thus mitigate electron transfer. Following the scheme we started from the basic calix[4]arene which was selectively protected with $n$-propyl groups on sites 26 and 28. Protected product $\mathbf{1 b}$ was then oxidized to quinone derivative $\mathbf{2 b}$ and bromine was introduced to the unoccupied sites. We tried to substitute the bromine on compound $\mathbf{3 b}$ with thioacetyl anchor group but reaction conditions used, did not furnish desired product. We believe that side reaction is occurring on the carbonyl groups of quinone center. To avoid possible side reactions, we reduced $\mathbf{3 b}$ to hydroquinone $\mathbf{4 b}$. In the next step, we tried to protect hydroxyl groups of hydroquinone with trimethylsilyl groups (TMS). Interestingly, on compound $\mathbf{5 b}$, upper-rim hydroxyl groups were protected only, while lower-rim stayed intact when using either $\mathrm{N}, \mathrm{O}$-bis(trimethylsilyl)acetamide (BSA) or trimethylsilyl chloride (TMSCl) (in the presence of triethylamine (TEA) or bis(trimethylsilyl)amine (HMDS)). On the other hand, TMSCl in the presence of the $\mathrm{NaH}$ yielded $\mathbf{6 b}$ where lower-rim $\mathrm{OH}$ groups were selectively protected, while upper-rim groups stayed intact. This interesting phenomenon is probably a combination of steric effects and non-covalent interactions of $\mathrm{Na}^{+}$cations with calix[4]arene macrocycle. Despite the fact that we have failed to protect the hydroxyl groups of $\mathbf{4 b}$ with TMS, we have shown new selective synthesis strategy, which can be used in designing new molecules. However, the protection of $-\mathrm{OH}$ groups on $\mathbf{4 b}$ was successful when using less bulky $n$-propyl groups, yielding compound $\mathbf{7} \mathbf{b}_{\mathbf{1}}$ or methyl groups yielding $\mathbf{7} \mathbf{b}_{\mathbf{2}}$. In the next step we introduced thioacetyl anchor groups and obtain compound $\mathbf{8}$. The product $\mathbf{8}$ was then subject to oxidation in order to obtain redox-active quinone centers. Standard oxidation procedures did not furnish desired product, so the synthetic path was abandoned.

Using alternative synthetic path, we targeted the introduction of sulfide anchor functional groups. We again started from calix[4]arene, which was selectively protected with benzyl groups to furnish compound 1a. Protected compound was then brominated on positions 5 and 17 to isolate product 9a. In the next step we protected remaining two hydroxyl groups on the lower-rim, which yielded pro-

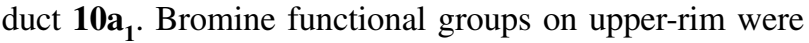
then substituted with methylsulfide group using an exchan-

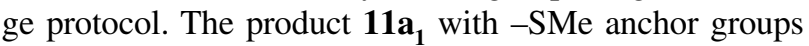
was then subject to deprotection of benzyl groups at lowerrim using trimethylsilyl bromide (TMSBr). The attempt to oxidize the deprotected product $\mathbf{1 2} \mathbf{a}_{1}$ and synthesize quinone derivative failed. Although the synthesis of the designed molecules did not yield the desired products, the intermediate products could be in the future tested for other applications such as redox shuttles.

After two unsuccessful trials of introducing sulfur anchor groups to the upper-rim of calix[4]arene, we decided to introduce sulfur anchor groups to the lower-rim. Once again we started with calix[4]arene, which was selectively protected with functional groups already bearing sulfur containing anchor groups. We have successfully introduced three different functional groups containing sulfide anchor centers - 1d-g. All three compounds were then oxidized to final quinone derivative $\mathbf{2 d - g}$ in $10 \%$ to $58 \%$ yields.

For electrochemical comparison, the molecules with carboxyl functional groups at the lower-rim were also synthesized (Scheme 1). Slightly modified previously published method ${ }^{25}$ yielded selectively protected calix[4]arene $1 c$ with protected carboxyl groups. In the next step phenolic units were oxidized to yield the molecule $2 \mathbf{c}$ with quinone redox centers. In order to obtain carboxylic anchor groups, the tert-butyl groups were removed from $\mathbf{2 c}$ and molecule 13 was isolated. For electrochemical comparison, a reduced version - hydroquinone $\mathbf{1 4}$ was also synthesized from 13, applying $\mathrm{Na}_{2} \mathrm{~S}_{2} \mathrm{O}_{4}$ as a reducing agent.

Molecules 2f, 2g, 13 and 14 were then attached to the $\mathrm{Au}(111)$ single crystal surface using ex-situ (2f and 

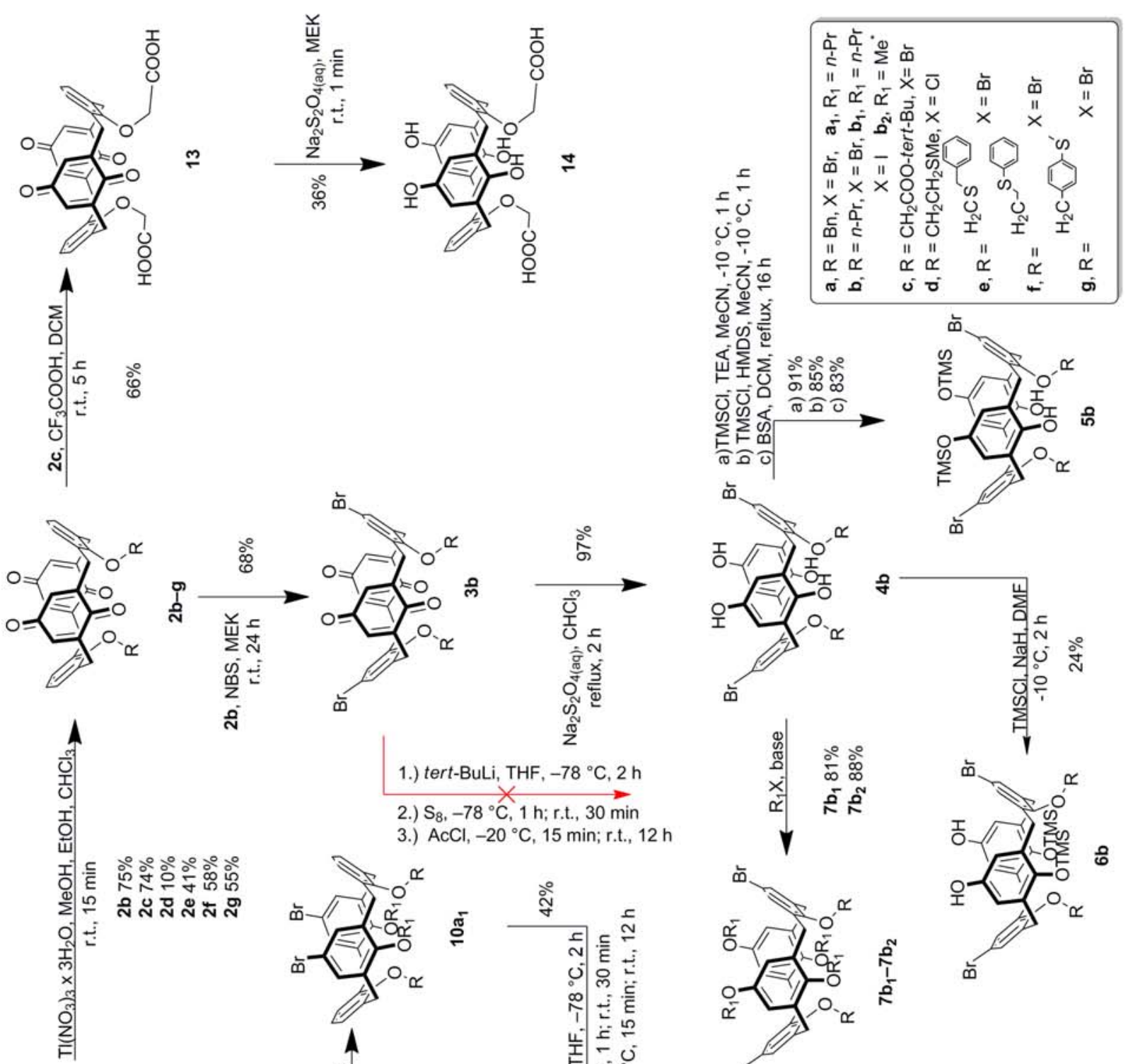

ตั

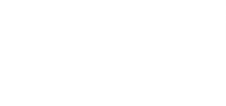




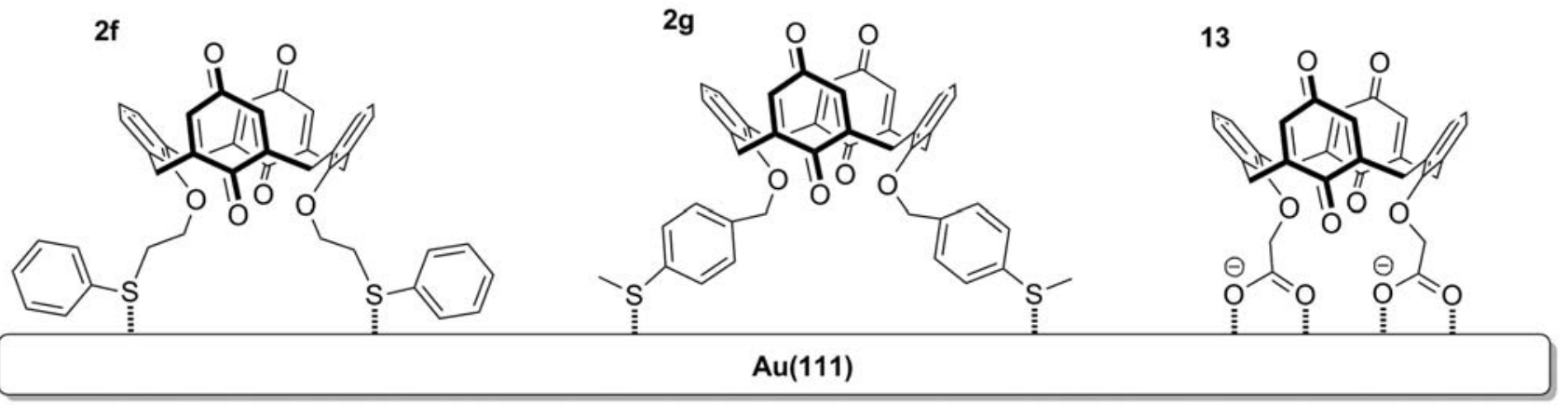

Figure 1. Self-assembled molecules at $\mathrm{Au}(111)$ single crystal surface. $\mathbf{2 f}$ and $\mathbf{2 g}$ were attached to the surface using ex-situ self-assembly method, 13 was attached using in-situ self-assembly method.

$\mathbf{2 g}$ ) and in-situ (13 and 14) self-assembly methods (Figure 1). Sulfide anchor groups in $\mathbf{2 f}$ and $\mathbf{2 g}$ were expected to bind to the gold through a dative bond. It was shown previously that sulfur can interact with $\mathrm{Au}(111)$ single crystal surfaces by donating the electron pair to the unoccupied Au orbitals. ${ }^{26}$ On the other hand in the case of the carboxyl anchor groups $(\mathbf{1 3}, \mathbf{1 4})$, ion-metal interaction was expected. In this respect, $\mathrm{pH}$ of self-assembly system and surface charge of the metal surface are playing significant role, thus in-situ self-assembly method was applied. Adsorption of the carboxylates has also been extensively studied over the past decades where several successful grafting methods were shown, ${ }^{27}$ including adsorption of electroactive anthraquinone-2carboxylic acid on gold surface. ${ }^{28}$

To evaluate the electrochemical response of the adsorbed molecules on the $\mathrm{Au}(111)$ single crystal surface, cyclic voltammetry (CV) was used. Molecules 2f, 2g, 13, and $\mathbf{1 4}$ on $\mathrm{Au}(111)$ were tested and their faradaic currents were measured. All chemically modified $\mathrm{Au}(111)$ electrodes showed specific faradaic response. Molecule $2 \mathbf{f}$ with long and bulky sulfide anchor groups showed stable redox activity in the potential region from $0.1 \mathrm{~V}$ to $1.15 \mathrm{~V}$ vs. reversible hydrogen electrode (RHE). The reaction is quasireversible (Figure 2). In the first cycle (Figure 2, black line) the anodic scan shows at least two peak potentials $\left(\mathrm{Ep}_{\mathrm{a}}\right)$ at $0.65 \mathrm{~V}$ and $0.88 \mathrm{~V}$ while cathodic scan shows three peak potentials $\left(\mathrm{Ep}_{\mathrm{c}}\right)$ at $0.77 \mathrm{~V}, 0.56 \mathrm{~V}$, and $0.43 \mathrm{~V}$. Redox mechanisms of diquinone derivatives of cali[4]arene in aprotic organic solvents have been studied previously. ${ }^{29}$ Authors suggest that there are two consecutive one-electron transfers followed by simultaneous concerted twoelectron transfer, giving the ionized hydroquinone (Scheme 2). Another study noticed change of the mechanism in the presence of water to concerted four-electron transfer per two quinone units. ${ }^{30}$ According to above mentioned and recorded $\mathrm{CV}$, we can presume that the mechanism of the $2 \mathbf{f}$ on $\mathrm{Au}(111)$ electrode could follow two consecutive one-electron transfers followed by concerted two-electron transfer in the first cycle.

However, after several cycles the shape of the CVs changed dramatically. $\mathrm{Ep}_{\mathrm{a}}$ at $0.88 \mathrm{~V}$ lost intensity, while $\mathrm{Ep}_{\mathrm{a}}$ at $0.65 \mathrm{~V}$ substantially increased. Similar was observed for the cathodic scan. $\mathrm{Ep}_{\mathrm{c}}$ at $0.43 \mathrm{~V}$ diminished while $\mathrm{Ep}_{\mathrm{c}}$ at $0.56 \mathrm{~V}$ increased. The reasons for the $\mathrm{CV}$ changes are unclear. One of the reasons could be, that the molecules on the $\mathrm{Au}(111)$ are rearranging and position of the redox centers are, in respect to the electrode, changing. Similar is happening with the molecules $\mathbf{2 g}$ on $\mathrm{Au}(111)$ surface.

Scan in the anodic direction reveals single $\mathrm{Ep}_{\mathrm{a}}$ at $0.88 \mathrm{~V}$ while the reverse scan in the cathodic direction, single peak $\mathrm{Ep}_{\mathrm{c}}$ at $0.33 \mathrm{~V}$ (Figure 3). After cycling in the defined potential window the $\mathrm{Ep}_{\mathrm{a}}$ shifted to $0.67 \mathrm{~V}$ and $\mathrm{Ep}_{\mathrm{c}}$ to $0.56 \mathrm{~V}$. This was the most pronounced when we held the potential at $-0.1 \mathrm{~V}$ for $1 \mathrm{~h}$. The peak potential separation $\Delta$ Ep is becoming smaller, thus one can conclude that reac-

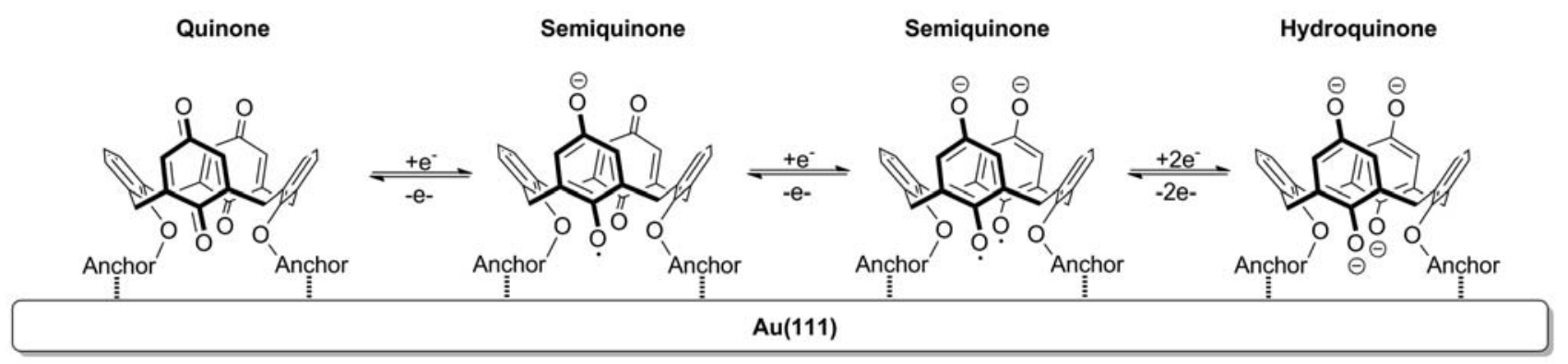

Scheme 2. Redox mechanism of electroactive diquinone derivatives of calix[4]arene with anchoring functional groups. 


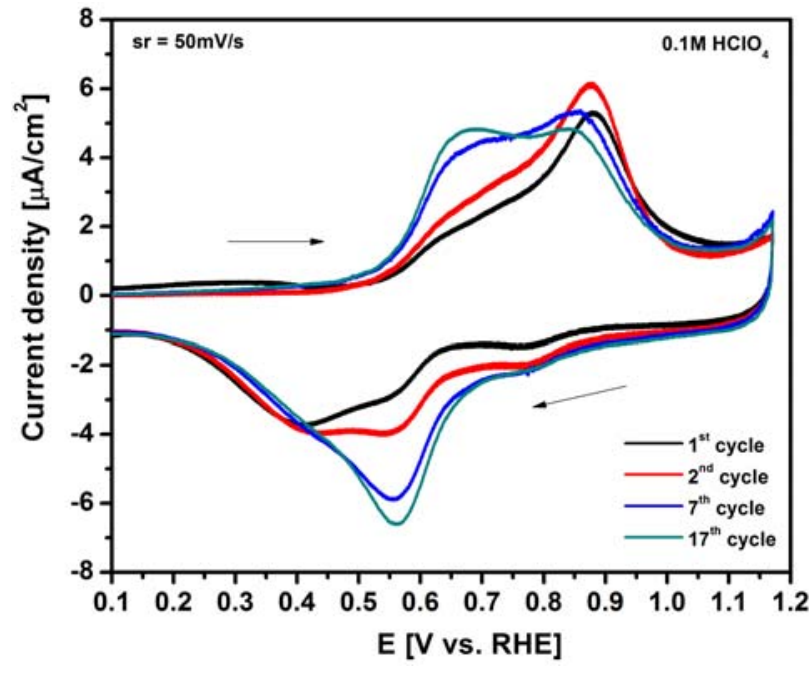

Figure 2. CVs of $\mathbf{2 f}$ bound to $\mathrm{Au}(111)$. Black line $-1^{\text {st }}$ cycle, red line $-2^{\text {nd }}$ cycle, blue line $-7^{\text {th }}$ cycle, and green line $-17^{\text {th }}$ cycle. Conditions: $0.1 \mathrm{M} \mathrm{HClO}_{4}$, at room temperature, applying $50 \mathrm{mV} / \mathrm{s} \mathrm{scan}$ rate. Arrows indicate direction of $\mathrm{CV}$ scan.

tion is getting more reversible. As mentioned above, the reason could be; the rearrangement of the self-assembled layer of the molecules on the $\mathrm{Au}(111)$ surface and change of the mechanism from two consecutive one-electron transfers followed by simultaneous concerted two-electron transfer to concerted four-electron transfer. In order to confirm that, extensive studies should be done, however, this is beyond the scope of this work.

The electrochemical investigation of the molecule with carboxylate anchor groups $\mathbf{1 3}$ on the $\mathrm{Au}(111)$ surfaces showed even more pronounced redox changes during cycling (Figure 4). To highlight the response of the redox

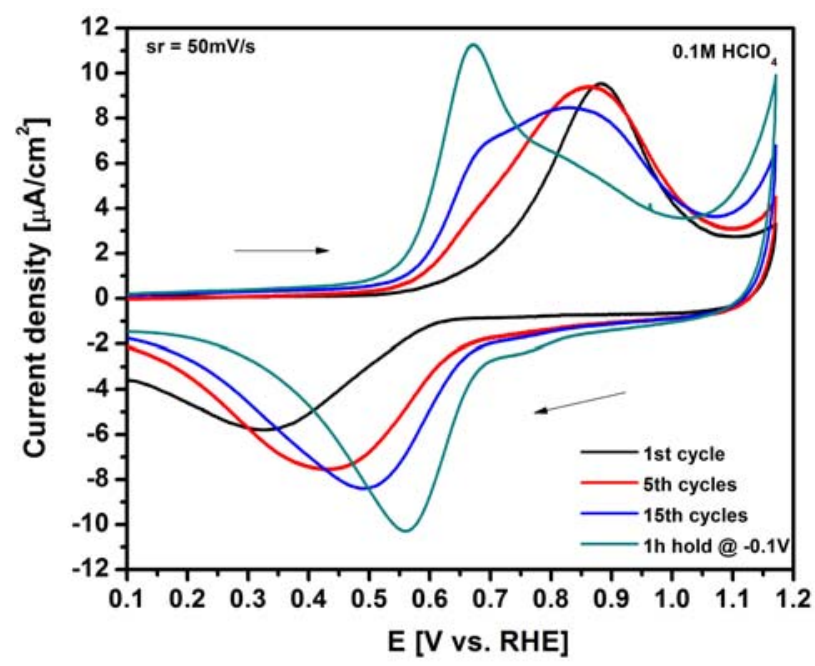

Figure 3. CVs of $2 \mathrm{~g}$ bound to $\mathrm{Au}(111)$. Black line $-1^{\text {st }}$ cycle, red line $-5^{\text {th }}$ cycle, blue line $-15^{\text {th }}$ cycle, and green line $-1 \mathrm{~h}$ hold at $-0.1 \mathrm{~V}$. Conditions: $0.1 \mathrm{M} \mathrm{HClO}_{4}$, at room temperature, applying 50 $\mathrm{mV} / \mathrm{s}$ scan rate. Arrows indicate direction of $\mathrm{CV}$ scan. electrochemistry of $\mathbf{1 3}$ the $\mathrm{CV}$ of pure $\mathrm{Au}(111)$ is overlaid in the Figure 4. The first scan of $\mathbf{1 3}$ on $\mathrm{Au}(111)$ exhibited distinct electrochemical response with at least four peaks. Redox processes are reversible with $\mathrm{Ep}_{\mathrm{a}}$ at $0.53 \mathrm{~V}, 0.63 \mathrm{~V}$, $0.70 \mathrm{~V}$, and $0.88 \mathrm{~V}$ and $\mathrm{Ep}_{\mathrm{c}}$ at $0.50 \mathrm{~V}, 0.57 \mathrm{~V}, 0.71 \mathrm{~V}$, and $0.86 \mathrm{~V}$. After the third cycle, CVs stabilized and did not change significantly. However, the difference between first and third cycle is significant. In the third cycle only one $\mathrm{Ep}_{\mathrm{a}}$ at $0.70 \mathrm{~V}$ can be seen and two $\mathrm{Ep}_{\mathrm{c}}$ at $0.55 \mathrm{~V}, 0.56 \mathrm{~V}$. Interestingly, when $\mathrm{CV}$ of $3^{\text {rd }}$ cycle of quinone derivative of calix[4]arene $\mathbf{1 3}$ was compared to $\mathrm{CV}$ of $1^{\text {st }}$ cycle of reduced version - a hydoquinone derivative of calix[4]arene 14 (Figure 5c and 5d), the CVs almost overlapped. One would expect to see overlapping of the CVs in the first cycles since we are probing the same molecule but in different oxidation state. However, the molecules on the surface are immediately reduced when electrode is immersed at lower potential. From above mentioned observation we can deduct that molecule $\mathbf{1 3}$ is rearranging on the surface and making more accessible to the protons from the electrolyte which are protonating phenoxide anion of the hydroquinone molecules. Once the film is thermodynamically stable the electrochemical response give the same results for either oxidized quinone $\mathbf{1 3}$ or reduced hydroquinone 14.

To evaluate the possible effect of the anchor groups, conditioned CVs of molecules 2f, $2 \mathrm{~g}, 13$ and 14 on $\mathrm{Au}(111)$ were compared (Figure 5). Surprisingly, all molecules exhibit similar electrochemical response with faradaic currents in anodic scan at $\mathrm{Ep}_{\mathrm{a}}-0.67 \mathrm{~V}$ and cathodic scan at $\mathrm{Ep}_{\mathrm{c}}-0.56 \mathrm{~V}$. Although the $\Delta \mathrm{Ep}(0.11 \mathrm{~V})$ of the main electrochemical reaction is the same for all four compounds, there are differences between the CVs which indicate different mechanism either in the anodic scan for

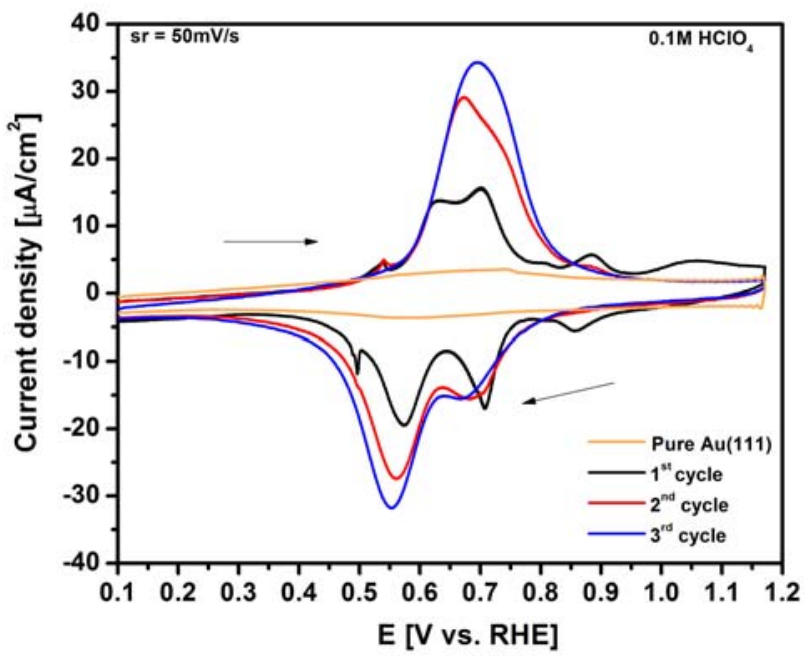

Figure 4. CVs of pure $\mathrm{Au}(111)$ (orange line) and $\mathbf{1 3}$ bound to $\mathrm{Au}(111)$. Black line $-1^{\text {st }}$ cycle, red line $-2^{\text {nd }}$ cycle, and blue line $3^{\text {rd }}$ cycle. Conditions: $0.1 \mathrm{M} \mathrm{HClO}_{4}$, at room temperature, applying $50 \mathrm{mV} / \mathrm{s}$ scan rate. Arrows indicate direction of $\mathrm{CV}$ scan. 


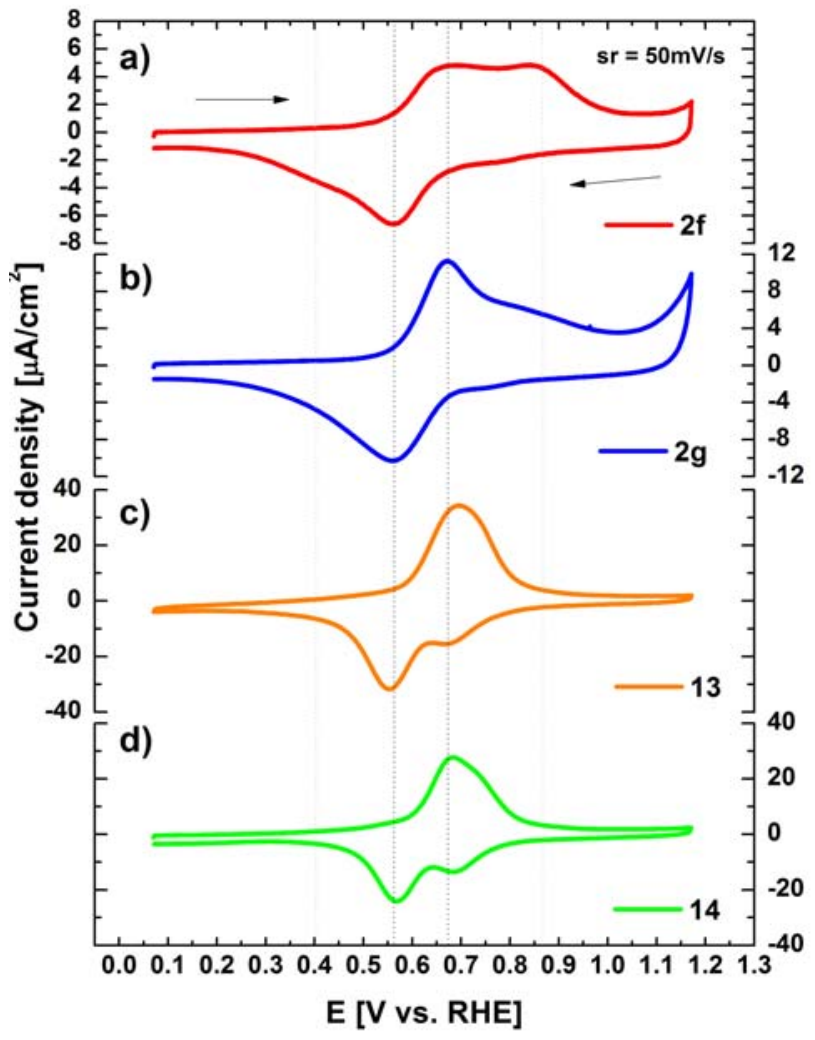

Figure 5. Comparison of stable CVs of quinone and hydroquinone derivatives of calix[4]arene: a) $2 \mathbf{f}$ bound to $\mathrm{Au}(111), 17^{\text {th }}$ cycle, b) $\mathbf{2 g}$ bound to $\mathrm{Au}(111), 1 \mathrm{~h}$ hold at $-0.1 \mathrm{~V}$ c) 13 bound to $\mathrm{Au}(111), 3^{\text {rd }}$ cycle, and d) 14 bound to $\mathrm{Au}(111), 1^{\text {st }}$ cycle. Conditions: $0.1 \mathrm{M} \mathrm{HC}-$ $1 \mathrm{O}_{4}$, at room temperature, applying $50 \mathrm{mV} / \mathrm{s}$ scan rate. Arrows indicate direction of $\mathrm{CV}$ scan.

$\mathbf{2 f}$ and $\mathbf{2 g}$ or the cathodic scan for $\mathbf{1 3}$ and $\mathbf{1 4}$. According to previously published results, ${ }^{30}$ one would expect that the reduction of all four diquinone compounds would undergo a concerted four-electron reduction in acidic aqueous media. However, the conditioning of the chemically modified $\mathrm{Au}(111)$ electrodes shows that all the diquinones; $\mathbf{2 f}$, $\mathbf{2 g}$, and 13 bearing different anchor groups exhibit their unique electrochemical response with additional waves. One of the reasons for such behavior could be a specific steric effect of the molecules where one-electron transfer reactions followed by protonation are shielded and thus reaction intermediates are more stable. According to above mentioned we cannot draw any solid conclusions on the effect of the length of the anchor groups.

\section{Conclusions}

Specifically designed redox-active diquinone derivatives of calix[4]arene bearing various anchor functional were synthesized and fully characterized. Designed and synthesized electroactive molecules are particularly interesting for the energy conversion and storage systems e.g. Li-ion and beyond Li-ion batteries (cathode materials, redox shuttles), and redox-flow batteries. In an attempt to introduce thiol anchor functional groups on the upper-rim of the calix[4]arene macrocycle, we have developed the method where selective protection of the hydroquinone $-\mathrm{OH}$ groups either on lower-rim $(\mathbf{6 b})$ or on upper-rim $(\mathbf{5 b})$ was achieved. Further, we have successfully synthesized new derivatives of calix[4]arene with 1,4-dimethoxybenzene moieties (8) and 1-methoxy-4-(methylthio)benzene

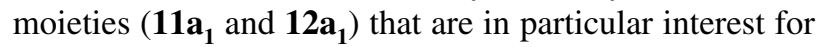
the non-aqueous redox flow batteries and as an overcharge protection for Li-ion batteries. We have also successfully synthesized diquinone derivatives of calix[4]arene with sulfide (2e, 2f, and $\mathbf{2 g}$ ) and carboxylate (13 and 14) anchor groups on lower-rim of the macrocycle. Above mentioned molecules could be used as an active cathode component of the $\mathrm{Li}$-ion and beyond $\mathrm{Li}$-ion batteries.

Molecules 2f, 2g, 13 and $\mathbf{1 4}$ were then attached to the $\mathrm{Au}(111)$ single crystal electrode using ex-situ and in-situ self-assembly methods and electrochemically characterized. All the analyzed molecules gave redox response in $0.1 \mathrm{M} \mathrm{HClO}_{4}$. It was noticed that electrochemical responses are changing during cycling for the molecules $2 \mathbf{2 f}, \mathbf{2 g}$, and 13. The positions of the peak potentials; $\mathrm{Ep}_{\mathrm{a}}$ and $\mathrm{Ep}_{\mathrm{c}}$ are shifting, increasing and decreasing. However, after conditioning the peak potentials; $\mathrm{Ep}_{\mathrm{a}}$ and $\mathrm{Ep}_{\mathrm{c}}$ stabilized and CVs did not change substantially. The conditioned CVs of $\mathbf{2 f}, \mathbf{2 g}, \mathbf{1 3}$ and $\mathbf{1 4}$ on $\mathrm{Au}(111)$ revealed two common peak potentials; $\mathrm{Ep}_{\mathrm{a}}$ at $0.67 \mathrm{~V}$ and $\mathrm{Ep}_{\mathrm{c}}$ at $0.56 \mathrm{~V}$ with the peak potential separation $\triangle \mathrm{Ep}-0.11 \mathrm{~V}$. The latter indicates that main redox mechanism of the different diquinone derivatives of calix[4]arene is similar while the presence of other peak potentials suggest that the full mechanism is complex and specific for the molecules tested.

\section{Experimental}

\section{1. Synthetic Materials and General Synthetic Procedures}

Reactions were performed in dried glassware under Ar atmosphere, unless stated otherwise. Precursor calix[4]arene was prepared according to literature procedures. ${ }^{31}$ Reagent grade tetrahydrofuran (THF) was distilled from $\mathrm{Na}$ and sodium benzophenone ketyl. Triethylamine (TEA) and $\mathrm{N}, \mathrm{N}$-dimethylformamide (DMF) were distilled over $\mathrm{CaH}_{2}$. Reagent grade hexanes, $\mathrm{CHCl}_{3}, \mathrm{CH}_{2} \mathrm{Cl}_{2}$ (DCM), $\mathrm{MeOH}$, and ethyl acetate (EtOAc) were used without further distillation. Acetyl chloride $(\mathrm{AcCl})$ was heated at reflux with $\mathrm{PCl}_{5}$ and then distilled. tert-Butyllithium titrated before use (1.46 M solution in pentane) was obtained from Aldrich. All other commercially available reagents were used as received. Flash column chromatography was performed using 230-400 mesh silica gel from EM Science. Thin layer chromatography was performed using 
glass plates pre-coated with silica gel $40 \mathrm{~F}_{254}$ purchased from Merck. ${ }^{1} \mathrm{H}$ spectra were taken at 400 or $300 \mathrm{MHz}$. ${ }^{13} \mathrm{C}$ NMR were recorded on the same instrument at 100.6 or $75.5 \mathrm{MHz}$, respectively. Proton chemical shifts (D) are reported in ppm downfield from tetramethylsilane (TMS). Carbon was referenced to $\mathrm{CDCl}_{3}(77.23 \mathrm{ppm})$, except when specified otherwise. Infrared spectroscopy (IR) spectra were recorded on Nicolet Avatar FTIR instrument. High resolution mass spectrometry (HRMS) was recorded on Q-Tof Premier, Waters-Micromass spectrometer.

General Procedure for synthesis of partially alkylated calix[4]arene (1). Calix[4]arene (3 g, $7.07 \mathrm{mmol})$ and $\mathrm{K}_{2} \mathrm{CO}_{3}(1.07 \mathrm{~g}, 7.77 \mathrm{mmol})$ were suspended in $\mathrm{MeCN}$ $(50 \mathrm{ml})$ and alkyl halide $(2.15 \mathrm{ml}, 14.21 \mathrm{mmol})$ was added. The reaction suspension was let to stir at the temperature of solvent boiling point, for $24 \mathrm{~h}$. After $24 \mathrm{~h} \mathrm{MeCN}$ was removed under reduced pressure, the remaining solid dissolved in $\mathrm{CHCl}_{3}(50 \mathrm{ml})$, and washed with $1 \mathrm{M} \mathrm{HCl}$ $(50 \mathrm{ml})$ and saturated aqueous solution of $\mathrm{NaCl}(50 \mathrm{ml})$. Organic phase was then separated from the aqueous and dried with $\mathrm{MgSO}_{4}$. Organic solvent was removed under reduced pressure and crude product purified by column chromatography (silica gel) or recrystallization.

General procedure for synthesis of diquinone derivative of calix[4]arene (2). A solution of $\mathrm{Tl}\left(\mathrm{NO}_{3}\right)_{3} \times 3 \mathrm{H}_{2} \mathrm{O}$ $(20.97 \mathrm{~g}, 47.18 \mathrm{mmol})$ in solvent mixture, $\mathrm{MeOH}(480 \mathrm{ml})$ and $\mathrm{EtOH}(1440 \mathrm{ml})$ was slowly added to the solution of 1 ( $4 \mathrm{~g}, 7.86 \mathrm{mmol})$ in $\mathrm{CHCl}_{3}$. Reaction mixture was let to stir for $15 \mathrm{~min}$ and then quenched by addition of $\mathrm{H}_{2} \mathrm{O}(200$ $\mathrm{ml}) .10 \%$ aqueous solution of $\mathrm{HCl}$ was then added dropwise until precipitate that formed during reaction did not dissolve. By applying reduced pressure, $\sim 80 \%$ of the solvents were removed and $\mathrm{CH}_{2} \mathrm{Cl}_{2}(100 \mathrm{~m})$ and $\mathrm{H}_{2} \mathrm{O}(50 \mathrm{ml})$ were added. Organic phase was separated from the aqueous and dried with $\mathrm{MgSO}_{4}$. Solvents were removed under reduced pressure and remaining solid purified by column chromatography (silica gel) or recrystallization.

General procedure for synthesis of alkoxy-calix[n]arene $(\mathbf{7}, \mathbf{1 0})$. Compound 7 or $\mathbf{1 0}(8.50 \mathrm{mmol})$ was added to the suspension of $\mathrm{NaH}(1.4 \mathrm{~g}, 59.50 \mathrm{mmol})$ in DMF (37 $\mathrm{ml})$ under inert atmosphere. Reaction mixture was let to stir at room temperature for $1 \mathrm{~h}$ and then alkyl halide (127.5 mmol) was added dropwise. Reaction mixture was then heated up to $60{ }^{\circ} \mathrm{C}$ and let to stir for $24 \mathrm{~h}$. DMF was removed under reduced pressure and remaining solid suspended in $\mathrm{CH}_{2} \mathrm{Cl}_{2}(50 \mathrm{ml})$. This was shook with saturated solution of $\mathrm{NH}_{4} \mathrm{Cl}(50 \mathrm{ml})$. Organic phase was separated from aqueous and dried with $\mathrm{MgSO}_{4} \cdot \mathrm{CH}_{2} \mathrm{Cl}_{2}$ was removed under reduced pressure and crude product purified by column chromatography or recrystallization.

Cone 26,28-bis(phenylmethoxy)-25,27-dihydroxycalix[4]arene (1a). Following the procedure for synthesis of partially alkylated calix[4]arene; calix[4]arene $(3 \mathrm{~g}, 7.07$ mmol), benzyl bromide $(1.72 \mathrm{ml}, 14.49 \mathrm{mmol}), \mathrm{K}_{2} \mathrm{CO}_{3}$ $(1.11 \mathrm{~g}, 8.06 \mathrm{mmol})$ and $\mathrm{MeCN}(90 \mathrm{ml})$ were used. Recrystallization from solvent mixture, $\mathrm{CHCl}_{3}-\mathrm{MeOH}$ yields colorless crystalline product $\left(3.56 \mathrm{~g}, 83 \%\right.$ yield). ${ }^{1} \mathrm{H}$ NMR $\left(300 \mathrm{MHz}, \mathrm{CDCl}_{3}\right): \Delta 7.82(\mathrm{~s}, 2 \mathrm{H}), 7.65(\mathrm{~m}, 4 \mathrm{H}), 7.36(\mathrm{~m}$, $6 \mathrm{H}), 7.05(\mathrm{~d}, J=7.5 \mathrm{~Hz}, 4 \mathrm{H}), 6.88(\mathrm{~d}, J=7.5 \mathrm{~Hz}, 4 \mathrm{H})$, $6.75-6.63(\mathrm{~m}, 4 \mathrm{H}), 5.06(\mathrm{~s}, 4 \mathrm{H}), 4.31(\mathrm{~d}, J=13.1 \mathrm{~Hz}, 4 \mathrm{H})$, $3.34(\mathrm{~d}, J=13.1 \mathrm{~Hz}, 4 \mathrm{H})$. The spectrum is in accordance with previously published results. ${ }^{32}$

Cone 26,28-di- $n$-propoxy-25,27- dihydroxycalix[4]arene (1b). Calix[4]arene (4 g, $9.42 \mathrm{mmol})$ was dissolved in $\mathrm{DMF}(87 \mathrm{ml})$ and $\mathrm{BaO}(8.41 \mathrm{~g}, 54.84 \mathrm{mmol}), \mathrm{Ba}(\mathrm{OH})_{2} \times$ $8 \mathrm{H}_{2} \mathrm{O}(8.95 \mathrm{~g}, 28.36 \mathrm{mmol})$, and 1-bromopropane (4.28 $\mathrm{ml}, 47.11 \mathrm{mmol}$ ) were added. Reaction mixture was let to stir over night at $50{ }^{\circ} \mathrm{C}$. After completion of reaction, $10 \%$ aqueous solution of $\mathrm{HCl}$ was added and extracted with $\mathrm{CH}_{2} \mathrm{Cl}_{2}$. Organic phase was separated from aqueous and dried with $\mathrm{MgSO}_{4}$. The solvents were removed under reduced pressure and remaining solid was recrystallized from solvent mixture $\mathrm{CHCl}_{3}-\mathrm{MeOH}$. Recrystallization yielded colorless crystalline product (3.68 g, 77\% yield). ${ }^{1} \mathrm{H}$ NMR (300 MHz, $\mathrm{CDCl}_{3}$ ): $\Delta 8.30$ (s, 2H), 7.05 (d, $J=$ $7.5 \mathrm{~Hz}, 4 \mathrm{H}), 6.91(\mathrm{~d}, J=7.5 \mathrm{~Hz}, 4 \mathrm{H}), 6.73-6.61(\mathrm{~m}, 4 \mathrm{H})$, $4.32(\mathrm{~d}, J=12.9 \mathrm{~Hz}, 4 \mathrm{H}), 3.97(\mathrm{t}, J=6.3 \mathrm{~Hz}, 4 \mathrm{H}), 3.37(\mathrm{~d}$, $J=12.9 \mathrm{~Hz}, 4 \mathrm{H}), 2.07(\mathrm{~m}, 4 \mathrm{H}), 1.31(\mathrm{t}, J=7.4 \mathrm{~Hz}, 6 \mathrm{H})$. The spectrum is in accordance with previously published results. $^{33}$

Cone 26,28-bis[(tert-butoxycarbonyl)methoxy]-25,27dihydroxycalix[4]arene (1c). Following the procedure for synthesis of partially alkylated calix[4]arene; calix[4]arene (1 g, $2.36 \mathrm{mmol})$, tert-butyl bromoacetate (0.71 ml, $4.83 \mathrm{mmol}), \mathrm{K}_{2} \mathrm{CO}_{3}(371 \mathrm{mg}, 2.69 \mathrm{mmol})$ and $\mathrm{MeCN}(30 \mathrm{ml})$ were used. Recrystallization from solvent mixture, $\mathrm{CHCl}_{3}-\mathrm{MeOH}$ yields colorless crystalline product (1.09 g, 71\% yield). ${ }^{1} \mathrm{H}$ NMR $\left(300 \mathrm{MHz}, \mathrm{CDCl}_{3}\right): \Delta$ $7.66(\mathrm{~s}, 2 \mathrm{H}), 7.04(\mathrm{~d}, J=7.5 \mathrm{~Hz}, 4 \mathrm{H}), 6.88(\mathrm{~d}, J=7.5 \mathrm{~Hz}$, $4 \mathrm{H}), 6.72-6.65(\mathrm{~m}, 4 \mathrm{H}), 4.58(\mathrm{~s}, 4 \mathrm{H}), 4.47(\mathrm{~d}, J=13.2 \mathrm{~Hz}$, $4 \mathrm{H}), 3.37(\mathrm{~d}, J=13.2 \mathrm{~Hz}, 4 \mathrm{H}), 1.56(\mathrm{~s}, 18 \mathrm{H})$. The spectrum is in accordance with previously published results. ${ }^{25}$

Cone 26,28-bis[2-(methylsulfanyl)ethoxy]-25,27-dihydroxycalix[4]arene (1d). Following the modified procedure (NaI was also used) for synthesis of partially alkylated calix[4]arene; calix[4]arene $(2.5 \mathrm{~g}, 5.89 \mathrm{mmol})$, 2-chloroethyl methyl sulfide ( $1.18 \mathrm{ml}, 12.07 \mathrm{mmol})$, $\mathrm{K}_{2} \mathrm{CO}_{3}(928 \mathrm{mg}, 6.71 \mathrm{mmol}), \mathrm{MeCN}(75 \mathrm{ml})$ and $\mathrm{NaI}$ (1.81 g, $12.07 \mathrm{mmol})$ were used. Column chromatography $\left(\mathrm{CH}_{2} \mathrm{Cl}_{2}: n\right.$-hexane $\left.2: 1\right)$ followed by recrystallization from solvent mixture $\mathrm{CHCl}_{3}-\mathrm{MeOH}$ yielded colorless crystalline product $\left(2.48 \mathrm{~g}, 74 \%\right.$ yield). ${ }^{1} \mathrm{H}$ NMR (300 $\left.\mathrm{MHz}, \mathrm{CDCl}_{3}\right): \Delta 7.56(\mathrm{~s}, 2 \mathrm{H}), 7.07(\mathrm{~d}, J=7.5 \mathrm{~Hz}, 4 \mathrm{H})$, $6.84(\mathrm{~d}, J=7.5 \mathrm{~Hz}, 4 \mathrm{H}), 6.71(\mathrm{~m}, 4 \mathrm{H}), 4.35(\mathrm{~d}, J=13.1$ $\mathrm{Hz}, 4 \mathrm{H}), 4.15(\mathrm{t}, J=6.7 \mathrm{~Hz}, 4 \mathrm{H}), 3.39(\mathrm{~d}, J=13.1 \mathrm{~Hz}$, $4 \mathrm{H}), 3.10(\mathrm{t}, J=6.7 \mathrm{~Hz}, 4 \mathrm{H}), 2.29(\mathrm{~s}, 6 \mathrm{H}) .{ }^{13} \mathrm{C} \mathrm{NMR}(75.5$ 
$\left.\mathrm{MHz}, \mathrm{CDCl}_{3}\right): \Delta 153.5,152.1,133.4,129.3,128.9,128.4$, 125.7, 119.4, 75.8, 33.9, 31.7, 16.7. HRMS: calcd for $\mathrm{C}_{34} \mathrm{H}_{36} \mathrm{O}_{4} \mathrm{~S}_{2}+\mathrm{H}^{+}$, 573.2133; found, 573.2125.

Cone 26,28-Bis[(benzylsulfanyl)methoxy]-25,27-dihydroxycalix[4]arene (1e). Following the procedure for synthesis of partially alkylated calix[4]arene; calix[4]arene $(2 \mathrm{~g}, 4.71 \mathrm{mmol})$, bromomethyl benzyl sulfide (1.46 $\mathrm{ml}, 9.66 \mathrm{mmol}), \mathrm{K}_{2} \mathrm{CO}_{3}(742 \mathrm{mg}, 5.37 \mathrm{mmol})$ and $\mathrm{MeCN}$ $(60 \mathrm{ml})$ were used. Column chromatography $\left(\mathrm{CH}_{2} \mathrm{Cl}_{2}\right.$ : $n$-hexane $2: 1)$ yielded white powder product $(1.71 \mathrm{~g}$, 52\% yield). IR (KBr): 3372, 3060, 3025, 2925, 1591, $1462 \mathrm{~cm}^{-1}$. ${ }^{1} \mathrm{H}$ NMR $\left(300 \mathrm{MHz}, \mathrm{CDCl}_{3}\right): \Delta 7.68(\mathrm{~s}, 2 \mathrm{H})$, $7.38-7.24(\mathrm{~m}, 10 \mathrm{H}), 7.09(\mathrm{~d}, J=7.5 \mathrm{~Hz}, 4 \mathrm{H}), 6.92(\mathrm{~d}, J=$ $7.5 \mathrm{~Hz}, 4 \mathrm{H}), 6.76(\mathrm{~m}, 4 \mathrm{H}), 5.08(\mathrm{~s}, 4 \mathrm{H}), 4.45$ (d, $J=13.2$ $\mathrm{Hz}, 4 \mathrm{H}), 4.05$ (s, 4H), 3.42 (d, $J=13.2 \mathrm{~Hz}, 4 \mathrm{H}) .{ }^{13} \mathrm{C}$ NMR $\left(75.5 \mathrm{MHz}, \mathrm{CDCl}_{3}\right): \Delta 153.6,151.9,137.6,133.9,129.8$, 129.6, 129.1, 128.6, 127.7, 126.4, 119.7, 116.4, 113.0, 77.9, 36.1, 32.6. HRMS: calcd for $\mathrm{C}_{44} \mathrm{H}_{40} \mathrm{O}_{4} \mathrm{~S}_{2}+\mathrm{Na}^{+}$, 719.2266; found, 719.2289.

Cone 26,28-bis[2-(phenylsulfanyl)ethoxy]-25,27-dihydroxycalix[4]arene (1f). Following the procedure for synthesis of partially alkylated calix[4]arene; calix[4]arene $(2 \mathrm{~g}, 4.71 \mathrm{mmol}), 2$-bromoethyl phenyl sulfide (1.46 $\mathrm{ml}, 9.66 \mathrm{mmol}), \mathrm{K}_{2} \mathrm{CO}_{3}(742 \mathrm{mg}, 5.37 \mathrm{mmol})$ and $\mathrm{MeCN}$ $(60 \mathrm{ml})$ were used. Column chromatography $\left(\mathrm{CH}_{2} \mathrm{Cl}_{2}\right.$ : $n$-hexane $2: 3$ ) followed by recrystallization from solvent mixture $\mathrm{CH}_{2} \mathrm{Cl}_{2}-\mathrm{MeOH}$ yielded colorless crystalline product (1.3 g, $40 \%$ yield). ${ }^{1} \mathrm{H}$ NMR (300 $\left.\mathrm{MHz}, \mathrm{CDCl}_{3}\right)$ : $\Delta 7.75(\mathrm{~s}, 2 \mathrm{H}), 7.44-7.17(\mathrm{~m}, 10 \mathrm{H}), 7.05(\mathrm{~d}, J=7.5 \mathrm{~Hz}$, $4 \mathrm{H}), 6.85(\mathrm{~d}, J=7.5 \mathrm{~Hz}, 4 \mathrm{H}), 6.67(\mathrm{~m}, 4 \mathrm{H}), 4.30(\mathrm{~d}, J=$ $13.1 \mathrm{~Hz}, 4 \mathrm{H}), 4.16(\mathrm{t}, J=7.2 \mathrm{~Hz}, 4 \mathrm{H}), 3.56(\mathrm{t}, J=7.2 \mathrm{~Hz}$, $4 \mathrm{H}), 3.35(\mathrm{~d}, J=13.1 \mathrm{~Hz}, 4 \mathrm{H}) .{ }^{13} \mathrm{C}$ NMR $(75.5 \mathrm{MHz}$, $\left.\mathrm{CDCl}_{3}\right): \Delta 153.5,151.8,135.6,133.5,130.2,129.5,129.3$, 128.9, 128.7, 128.5, 126.9, 125.8, 119.5, 74.7, 33.3, 31.7. HRMS: calcd for $\mathrm{C}_{44} \mathrm{H}_{40} \mathrm{O}_{4} \mathrm{~S}_{2}+\mathrm{Na}^{+}, 719.2266$; found, 719.2280. The data is in accordance with previously published results. ${ }^{34}$

Cone 26,28-Bis[(4-methylthio)benzyl]-25,27-dihydroxycalix[4]arene (1g). Following the procedure for synthesis of partially alkylated calix[4]arene; calix[4]arene (1 g, $2.36 \mathrm{mmol})$, 4-(methylthio)benzyl bromide (1.05 $\mathrm{g}, 4.83 \mathrm{mmol}), \mathrm{K}_{2} \mathrm{CO}_{3}(371 \mathrm{mg}, 2.69 \mathrm{mmol})$ and $\mathrm{MeCN}$ $(30 \mathrm{ml})$ were used. Recrystallization from solvent mixture $\mathrm{CH}_{2} \mathrm{Cl}_{2}-\mathrm{MeOH}$ yielded colorless crystalline product (1.38 g, 84\% yield). IR (KBr): 3406, 3022, 2921, 2858, $1595,1462 \mathrm{~cm}^{-1} .{ }^{1} \mathrm{H}$ NMR $\left(300 \mathrm{MHz}, \mathrm{CDCl}_{3}\right): \Delta 7.78(\mathrm{~s}$, 2H), $7.56(\mathrm{~d}, J=8.3 \mathrm{~Hz}, 4 \mathrm{H}), 7.25(\mathrm{~d}, J=8.3 \mathrm{~Hz}, 4 \mathrm{H})$, 7.04 (d, $J=7.5 \mathrm{~Hz}, 4 \mathrm{H}), 6.87$ (d, $J=7.5 \mathrm{~Hz}, 4 \mathrm{H}), 6.67(\mathrm{~m}$, 4H), 5.02 (s, 4H), 4.28 (d, $J=13.1 \mathrm{~Hz}, 4 \mathrm{H}), 3.33$ (d, $J=$ $13.1 \mathrm{~Hz}, 4 \mathrm{H}) .{ }^{13} \mathrm{C}$ NMR $\left(75.5 \mathrm{MHz}, \mathrm{CDCl}_{3}\right): \Delta$ 153.6, 152.2 , 138.9, 133.9, 133.6, 129.4, 128.9, 128.4, 128.3, 127.0, 125.8, 119.4, 78.3, 31.8, 16.2. HRMS: calcd for $\mathrm{C}_{44} \mathrm{H}_{40} \mathrm{O}_{4} \mathrm{~S}_{2}+\mathrm{Na}^{+}$, 719.2266; found, 719.2250.
Cone 11,26,23,28-tetraone-25,27-dipropoxycalix[4] arene $(\mathbf{2 b})$. Following the procedure for synthesis of diquinone derivative of calix[4]arene; compound $\mathbf{1 b}$ (4 g, $7.86 \mathrm{mmol}), \mathrm{Tl}\left(\mathrm{NO}_{3}\right)_{3} \times 3 \mathrm{H}_{2} \mathrm{O}(20.97 \mathrm{~g}, 47.18 \mathrm{mmol})$, $\mathrm{MeOH}(480 \mathrm{ml})$, EtOH $(1440 \mathrm{ml}), \mathrm{CHCl}_{3}(400 \mathrm{ml})$ and $\mathrm{H}_{2} \mathrm{O}(200 \mathrm{ml})$ were used. Recrystallization from solvent mixture $\mathrm{CH}_{2} \mathrm{Cl}_{2}-\mathrm{MeOH}$ at $4{ }^{\circ} \mathrm{C}$, yielded orange crystalline product $\left(3.16 \mathrm{~g}, 75 \%\right.$ yield). ${ }^{1} \mathrm{H}$ NMR $(300 \mathrm{MHz}$, $\left.\mathrm{CDCl}_{3}\right): \Delta 6.80(\mathrm{~d}, J=7.4 \mathrm{~Hz}, 4 \mathrm{H}), 6.63(\mathrm{~m}, 6 \mathrm{H}), 3.81(\mathrm{~d}$, $J=12.7 \mathrm{~Hz}, 4 \mathrm{H}), 3.65(\mathrm{t}, J=7.1 \mathrm{~Hz}, 4 \mathrm{H}), 3.32(\mathrm{~d}, J=12.7$ $\mathrm{Hz}, 4 \mathrm{H}), 1.81(\mathrm{~m}, 4 \mathrm{H}), 1.00(\mathrm{t}, J=7.5 \mathrm{~Hz}, 6 \mathrm{H})$. The spectrum is in accordance with previously published results. ${ }^{35}$

Cone 11,26,23,28-tetraone-25,27-bis[(tert-butoxycarbonyl)methoxy]-calix[4]arene (2c). Following the procedure for synthesis of diquinone derivative of calix[4] arene; compound 1c (500 mg, $0.77 \mathrm{mmol}), \mathrm{Tl}\left(\mathrm{NO}_{3}\right)_{3}$ $\times 3 \mathrm{H}_{2} \mathrm{O}(2.04 \mathrm{~g}, 4.60 \mathrm{mmol}), \mathrm{MeOH}(60 \mathrm{ml}), \mathrm{EtOH}(180$ $\mathrm{ml}), \mathrm{CHCl}_{3}(50 \mathrm{ml})$ and $\mathrm{H}_{2} \mathrm{O}(25 \mathrm{ml})$ were used. Column chromatography $\left(\mathrm{CH}_{2} \mathrm{Cl}_{2}\right.$ : EtOAc $\left.3: 1\right)$ yielded orange powder product $\left(386 \mathrm{mg}, 74 \%\right.$ yield). ${ }^{1} \mathrm{H}$ NMR (300 $\left.\mathrm{MHz}, \mathrm{CDCl}_{3}\right): \Delta 6.82(\mathrm{~d}, J=7.4 \mathrm{~Hz}, 4 \mathrm{H}), 6.74(\mathrm{~s}, 4 \mathrm{H})$, $6.66(\mathrm{~m}, 2 \mathrm{H}), 4.34$ (s, 4H), 3.96 (d, $J=12.4 \mathrm{~Hz}, 4 \mathrm{H}), 3.36$ $(\mathrm{d}, J=12.4 \mathrm{~Hz}, 4 \mathrm{H}), 1.49(\mathrm{~s}, 18 \mathrm{H})$. The spectrum is in accordance with previously published results. ${ }^{25}$

Cone 11,26,23,28-tetraone-25,27-bis[2-(methylsulfanyl)ethoxy]-calix[4]arene (2d). Following the procedure for synthesis of diquinone derivative of calix[4]arene; compound $1 d$ (50 mg, $0.09 \mathrm{mmol}), \mathrm{Tl}\left(\mathrm{NO}_{3}\right)_{3} \times 3 \mathrm{H}_{2} \mathrm{O}$ (233 mg, $0.52 \mathrm{mmol}), \mathrm{MeOH}(6 \mathrm{ml}), \mathrm{EtOH}(18 \mathrm{ml})$, $\mathrm{CHCl}_{3}(5 \mathrm{ml})$ and $\mathrm{H}_{2} \mathrm{O}(2.5 \mathrm{ml})$ were used. Column chromatography $\left(\mathrm{CH}_{2} \mathrm{Cl}_{2}\right.$ : EtOAc $\left.10: 1\right)$ yielded orange powder product ( $5 \mathrm{mg}, 10 \%$ yield). IR (KBr): 3063, 2921, 2866, 1656, 1459, 1292, $1200 \mathrm{~cm}^{-1}$. ${ }^{1} \mathrm{H}$ NMR $(300 \mathrm{MHz}$, $\left.\mathrm{CDCl}_{3}\right): \Delta 6.81(\mathrm{~d}, J=7.4 \mathrm{~Hz}, 4 \mathrm{H}), 6.65(\mathrm{~m}, 6 \mathrm{H}), 3.90(\mathrm{~m}$, $8 \mathrm{H}), 3.33(\mathrm{~d}, J=12.9 \mathrm{~Hz}, 4 \mathrm{H}), 2.85$ (t, $J=6.5 \mathrm{~Hz}, 4 \mathrm{H})$, $2.18(\mathrm{~s}, 6 \mathrm{H}) .{ }^{13} \mathrm{C}$ NMR $\left(75.5 \mathrm{MHz}, \mathrm{CDCl}_{3}\right): \Delta$ 188.5, 186.2, 148.4, 132.5, 130.2, 123.9, 93.2, 74.2, 46.0, 34.2, 31.7. HRMS: calcd for $\mathrm{C}_{34} \mathrm{H}_{32} \mathrm{O}_{6} \mathrm{~S}_{2}+\mathrm{H}^{+}, 601.1719$; found, 601.1738 .

Cone 11,26,23,28-tetraone-25,27-bis[(benzylsulfanyl) methoxy]-calix[4]arene (2e). Following the procedure for synthesis of diquinone derivative of calix[4]arene; compound 1e (500 mg, $0.72 \mathrm{mmol}), \mathrm{Tl}\left(\mathrm{NO}_{3}\right)_{3} \times 3 \mathrm{H}_{2} \mathrm{O}$ (1.91 g, $4.30 \mathrm{mmol}), \mathrm{MeOH}(60 \mathrm{ml}), \mathrm{EtOH}(180 \mathrm{ml})$, $\mathrm{CHCl}_{3}(50 \mathrm{ml})$ and $\mathrm{H}_{2} \mathrm{O}(25 \mathrm{ml})$ were used. Column chromatography $\left(\mathrm{CH}_{2} \mathrm{Cl}_{2}\right.$ : EtOAc $\left.15: 1\right)$ yielded orange powder product (215 mg, $41 \%$ yield). IR (KBr): 3060, 3028, 2923, 1653, 1459, $1293 \mathrm{~cm}^{-1}$. ${ }^{1} \mathrm{H}$ NMR (300 MHz, $\left.\mathrm{CDCl}_{3}\right): \Delta 7.35-7.15(\mathrm{~m}, 10 \mathrm{H}), 6.79-6.66 .(\mathrm{m}, 10 \mathrm{H}), 4.91$ (s, 4H), 4.05 (d, J = 13.0 Hz, 4H), 3.73 (s, 4H), 3.23 (d, J $=13.0 \mathrm{~Hz}, 4 \mathrm{H}) .{ }^{13} \mathrm{C} \mathrm{NMR}\left(75.5 \mathrm{MHz}, \mathrm{CDCl}_{3}\right): \Delta 188.9$, $187.9,187.6,151.4,148.8,148.7,148.1,137.7,133.3$, $129.5,129.1$, 128.5, 127.0, 126.3, 121.7, 64.5, 34.4, 30.7. 
HRMS: calcd for $\mathrm{C}_{44} \mathrm{H}_{36} \mathrm{O}_{6} \mathrm{~S}_{2}+\mathrm{H}^{+}$, 725.2032; found, 725.2058.

\section{Cone 11,26,23,28-tetraone-25,27-bis[2-(phenylsul-} fanyl)ethoxy]-calix[4]arene (2f). Following the procedure for synthesis of diquinone derivative of calix[4]arene; compound 1f $(500 \mathrm{mg}, 0.72 \mathrm{mmol}), \mathrm{Tl}\left(\mathrm{NO}_{3}\right)_{3} \times 3 \mathrm{H}_{2} \mathrm{O}$ $(1.91 \mathrm{~g}, 4.30 \mathrm{mmol}), \mathrm{MeOH}(60 \mathrm{ml})$, EtOH $(180 \mathrm{ml})$, $\mathrm{CHCl}_{3}(50 \mathrm{ml})$ and $\mathrm{H}_{2} \mathrm{O}(25 \mathrm{ml})$ were used. Column chromatography $\left(\mathrm{CH}_{2} \mathrm{Cl}_{2}\right.$ : EtOAc $\left.20: 1\right)$ yielded orange powder product (300 mg, 58\% yield). IR ( $\mathrm{KBr}): 3056,2957$, 2923, 2868, 1656, 1459, $1288 \mathrm{~cm}^{-1} .{ }^{1} \mathrm{H}$ NMR $(300 \mathrm{MHz}$, $\left.\mathrm{CDCl}_{3}\right): \Delta 7.35-7.15(\mathrm{~m}, 10 \mathrm{H}), 6.74-6.56 .(\mathrm{m}, 10 \mathrm{H})$, 3.87-3.83 (m, 8H), 3.25-3.21 (m, 8H). ${ }^{13} \mathrm{C}$ NMR $(75.5$ $\left.\mathrm{MHz}, \mathrm{CDCl}_{3}\right): \Delta 188.5,186.1,155.9,148.3,135.6,132.6$, 130.3, 130.1, 129.7, 129.4, 126.9, 124.0, 73.1, 33.9, 31.8. HRMS: calcd for $\mathrm{C}_{44} \mathrm{H}_{36} \mathrm{O}_{6} \mathrm{~S}_{2}+\mathrm{Na}^{+}, 747.1851$; found, 747.1847.

Cone 11,26,23,28-tetraone-25,27-bis[(4-methylthio) benzyl]-kaliks[4]aren (2g). Following the procedure for synthesis of diquinone derivative of calix[4]arene; compound $1 \mathrm{~g}(500 \mathrm{mg}, 0.72 \mathrm{mmol}), \mathrm{Tl}\left(\mathrm{NO}_{3}\right)_{3} \times 3 \mathrm{H}_{2} \mathrm{O}(1.91 \mathrm{~g}$, $4.30 \mathrm{mmol}), \mathrm{MeOH}(60 \mathrm{ml}), \mathrm{EtOH}(180 \mathrm{ml}), \mathrm{CHCl}_{3}(50$ $\mathrm{ml})$ and $\mathrm{H}_{2} \mathrm{O}(25 \mathrm{ml})$ were used. Column chromatography $\left(\mathrm{CH}_{2} \mathrm{Cl}_{2}\right.$ : EtOAc $\left.10: 1\right)$ yielded orange powder product (288 mg, 55\% yield). IR (KBr): 3026, 2960, 2921, 2859, 1656, 1459, $1293 \mathrm{~cm}^{-1} .{ }^{1} \mathrm{H}$ NMR $\left(300 \mathrm{MHz}, \mathrm{CDCl}_{3}\right): \Delta$ 7.24-7.17 (m, 8H), 6.79. (d, $J=7.5 \mathrm{~Hz}, 4 \mathrm{H}), 6.65(\mathrm{t}, J=$ $7.5 \mathrm{~Hz}, 2 \mathrm{H}), 6.48(\mathrm{~s}, 4 \mathrm{H}), 4.75(\mathrm{~s}, 4 \mathrm{H}), 3.65(\mathrm{~d}, J=12.6$ $\mathrm{Hz}, 4 \mathrm{H}), 3.14(\mathrm{~d}, J=12.6 \mathrm{~Hz}, 4 \mathrm{H}), 2.49(\mathrm{~s}, 6 \mathrm{H}) .{ }^{13} \mathrm{C}$ NMR $\left(75.5 \mathrm{MHz}, \mathrm{CDCl}_{3}\right): \Delta 188.5,186.2,156.1,148.2,139.2$, 133.7, 132.4, 130.6, 129.9, 129.2, 126.8, 123.9, 76.2, 32.1, 16,0. HRMS: calcd for $\mathrm{C}_{44} \mathrm{H}_{36} \mathrm{O}_{6} \mathrm{~S}_{2}+\mathrm{Na}^{+}, 747.1851$; found, 747.1879.

Cone 5,17-dibromo-11,26,23,28-tetraone-25,27-dipropoxycalix[4] arene (3b). Compound $2 \mathbf{b}(2 \mathrm{~g}, 3.73 \mathrm{mmol})$ and $N$-bromosuccinimide NBS $(2.26 \mathrm{~g}, 12.67 \mathrm{mmol})$ were dissolved in 2-butanone (MEK) $(90 \mathrm{ml})$ and catalytic amount of $48 \% \mathrm{HBr}(60 \mu \mathrm{l})$ was added. The reaction mixture was let to stir at room temperature in a dark place for $24 \mathrm{~h}$. The reaction mixture was quenched by addition of $10 \% \mathrm{NaHSO}_{3(\mathrm{aq})}(75 \mathrm{ml})$ and let to stir for $10 \mathrm{~min} . \mathrm{CH}_{2} \mathrm{Cl}_{2}$ $(100 \mathrm{ml})$ and organic phase was separated from aqueous. The latter was extracted with additional $\mathrm{CH}_{2} \mathrm{Cl}_{2}(3 \times 25$ $\mathrm{ml}$ ). Combined organic phases were dried with $\mathrm{MgSO}_{4}$ and then solvents were removed under the reduce pressure. Crude product purified by column chromatography $\left(\mathrm{CH}_{2} \mathrm{Cl}_{2}:\right.$ EtOAc $\left.15: 1\right)$ and recrystallized from solvent mixture $\left(\mathrm{CHCl}_{3}-\mathrm{MeOH}\right)$ to yield orange crystalline product $(1,77 \mathrm{~g}, 68 \%$ yield). IR (KBr): 2966, 2931, 2876, 1657, 1460, 1294, $1204 \mathrm{~cm}^{-1} .{ }^{1} \mathrm{H}$ NMR $(300 \mathrm{MHz}$, $\left.\mathrm{CDCl}_{3}\right): \Delta 7.01(\mathrm{~s}, 4 \mathrm{H}), 6.64(\mathrm{~s}, 4 \mathrm{H}), 3.79(\mathrm{~d}, J=13.3 \mathrm{~Hz}$, $4 \mathrm{H}), 3.63(\mathrm{t}, J=7.1 \mathrm{~Hz}, 4 \mathrm{H}), 3.28(\mathrm{~d}, J=13.3 \mathrm{~Hz}, 4 \mathrm{H})$, $1.80(\mathrm{~m}, 4 \mathrm{H}), 0.99(\mathrm{t}, J=7.4 \mathrm{~Hz}, 6 \mathrm{H}) .{ }^{13} \mathrm{C}$ NMR $(75.5$
$\left.\mathrm{MHz}, \mathrm{CDCl}_{3}\right): \Delta 188.3,185.7,156.1,147.3,133.1,132.4$, 116.4, 32.0, 23.9, 10.9. HRMS: calcd for $\mathrm{C}_{34} \mathrm{H}_{30} \mathrm{O}_{6} \mathrm{Br}_{2}+$ $\mathrm{H}^{+}$, 693.0487; found, 693.0510.

Cone 5,17-dibromo-11,26,23,28-tetrahydroxy-25,27dipropoxycalix[4]arene (4b). Compound $3 \mathrm{~b}$ (1.15 g, $1.65 \mathrm{mmol})$ was dissolved in $\mathrm{CHCl}_{3}(287 \mathrm{ml})$ and heated up to $70{ }^{\circ} \mathrm{C}$. Then $\mathrm{NaHSO}_{3 \text { (aq) }}(2.3 \mathrm{~g}, 13.2 \mathrm{mmol}$ in $34 \mathrm{ml}$ of $\mathrm{H}_{2} \mathrm{O}$ ) was added. Reaction mixture was let to stir at boiling point for $1.5 \mathrm{~h}$. Reaction mixture was then cooled down to room temperature and $\mathrm{H}_{2} \mathrm{O}(20 \mathrm{ml})$ was added. Organic phase was separated from aqueous and dried with $\mathrm{MgSO}_{4}$. Solvents were removed under reduced pressure and remaining solid recrystallized from solvent mixture $\left(\mathrm{CHCl}_{3}-n\right.$-hexane) to yield colorless crystalline product (1.12 g, 97\% yield). IR (KBr): 3376, 2963, 2928, 2874, 1656, 1460, $1204 \mathrm{~cm}^{-1} .{ }^{1} \mathrm{H}$ NMR $\left(300 \mathrm{MHz}, \mathrm{CDCl}_{3}\right): \Delta$ $7.79(\mathrm{~s}, 2 \mathrm{H}), 7.08(\mathrm{~s}, 4 \mathrm{H}), 6.55(\mathrm{~s}, 4 \mathrm{H}), 4.34(\mathrm{~s}, 2 \mathrm{H}) 4.24$ $(\mathrm{d}, J=12.9 \mathrm{~Hz}, 4 \mathrm{H}), 3.92(\mathrm{t}, J=6.4 \mathrm{~Hz}, 4 \mathrm{H}), 3.24(\mathrm{~d}, J=$ $12.9 \mathrm{~Hz}, 4 \mathrm{H}), 2.04(\mathrm{~m}, 4 \mathrm{H}), 1.27(\mathrm{t}, J=7.4 \mathrm{~Hz}, 6 \mathrm{H}) .{ }^{13} \mathrm{C}$ NMR $\left(75.5 \mathrm{MHz}, \mathrm{CDCl}_{3}\right): \Delta 151.7,148.4,147.4,135.9$, 132.3, 128.6, 118.1, 115.7, 79.1, 31.7, 23.7, 11.2. HRMS: calcd for $\mathrm{C}_{34} \mathrm{H}_{34} \mathrm{O}_{6} \mathrm{Br}_{2}+\mathrm{H}^{+}$, 697.0800; found, 697.0816.

Cone 5,17-dibromo-26,28-dihydroxy-11,23-bis[4-(trimethylsiloxy)]-25,27-dipropoxycalix[4]arene (5b). Compound $\mathbf{4 b}(200 \mathrm{mg}, 0.29 \mathrm{mmol})$ was suspended in mixture of $\mathrm{MeCN}(10 \mathrm{ml})$ and triethylamine (TEA) $(0.4$ $\mathrm{ml}, 2.86 \mathrm{mmol})$. Reaction mixture was then cooled down to $-10{ }^{\circ} \mathrm{C}$ and trimethylsilyl chloride (TMSCl) $(0.36 \mathrm{ml}$, $2.86 \mathrm{mmol}$ ) was slowly added. After $10 \mathrm{~min}$ of stirring at $10{ }^{\circ} \mathrm{C}$ a precipitate formed, this was filtrated and washed with $\mathrm{MeOH}$ to yield analytically pure product $(220 \mathrm{mg}$, 91\% yield). IR (KBr): 3369, 3060, 3023, 2926, 1591, 1464, 1263, $1215 \mathrm{~cm}^{-1}$. ${ }^{1} \mathrm{H}$ NMR (300 MHz, $\left.\mathrm{CDCl}_{3}\right): \Delta$ $7.84(\mathrm{~s}, 2 \mathrm{H}), 7.07(\mathrm{~s}, 4 \mathrm{H}), 6.55(\mathrm{~s}, 4 \mathrm{H}), 4.23(\mathrm{~d}, J=12.9$ $\mathrm{Hz}, 4 \mathrm{H}), 3.91(\mathrm{t}, J=6.2 \mathrm{~Hz}, 4 \mathrm{H}), 3.24(\mathrm{~d}, J=12.9 \mathrm{~Hz}$, $4 \mathrm{H}), 2.03(\mathrm{~m}, 4 \mathrm{H}), 1.29$ (t, $J=7.4 \mathrm{~Hz}, 6 \mathrm{H}), 0.24(\mathrm{~s}, 18 \mathrm{H})$. ${ }^{13} \mathrm{C}$ NMR (75.5 MHz, $\left.\mathrm{CDCl}_{3}\right): \Delta 151.5,148.0,147.3$, 135.8, 132.1, 127.9, 120.3, 117.9, 78.8, 31.6, 23.6, 11.1, 0.3. HRMS: calcd for $\mathrm{C}_{40} \mathrm{H}_{50} \mathrm{O}_{6} \mathrm{Si}_{2} \mathrm{Br}_{2}+\mathrm{Na}^{+}$, 863.1410; found, 863.1434.

Cone 5,17-dibromo-11,23-dihydroxy-26,28-bis[4-(trimethylsiloxy)]-25,27-dipropoxycalix[4]arene (6b). Na$\mathrm{H}(96 \mathrm{mg}, 4.01 \mathrm{mmol})$ was suspended in DMF $(7 \mathrm{ml})$ and 4b (280 mg, $0.40 \mathrm{mmol})$ was slowly - in parts - added to the suspension. After completed addition the reaction mixture was cooled down to $-10{ }^{\circ} \mathrm{C}$ and let to stir for 15 min. TMSCl (1.02 ml, $8.02 \mathrm{mmol})$ was then slowly added to the mixture and let to stir at room temperature for $2 \mathrm{~h}$. After $2 \mathrm{~h}$ the DMF was removed under reduced pressure, the remaining solid dissolved in $\mathrm{CH}_{2} \mathrm{Cl}_{2}$ and shook with $\mathrm{H}_{2} \mathrm{O}$. Organic phase was separated from aqueous, dried with $\mathrm{MgSO}_{4}$ and then solvents removed under reduced pressure. Column chromatography (EtOAc : $n$-hexane 1 : 
3) yielded white powder product ( $80 \mathrm{mg}, 24 \%$ yield). IR (KBr): 3333, 2961, 2920, 2875, 1598, 1459, 1288, 1252, $1215 \mathrm{~cm}^{-1} .{ }^{1} \mathrm{H}$ NMR $\left(300 \mathrm{MHz}, \mathrm{CDCl}_{3}\right): \Delta 7.23(\mathrm{~s}, 4 \mathrm{H})$, $5.58(\mathrm{~s}, 4 \mathrm{H}), 4.78(\mathrm{br} \mathrm{s}, 2 \mathrm{H}), 4.25(\mathrm{~d}, J=13.7 \mathrm{~Hz}, 4 \mathrm{H})$, $3.89(\mathrm{~m}, 4 \mathrm{H}), 2.97(\mathrm{~d}, J=13.7 \mathrm{~Hz}, 4 \mathrm{H}), 1.83(\mathrm{~m}, 4 \mathrm{H})$, $0.85(\mathrm{t}, J=7.4 \mathrm{~Hz}, 6 \mathrm{H}), 0.21(\mathrm{~s}, 18 \mathrm{H}) .{ }^{13} \mathrm{C}$ NMR $(75.5$ $\left.\mathrm{MHz}, \mathrm{CDCl}_{3}\right): \Delta 157.5,148.6,144.8,139.4,131.9,131.7$, 115.5, 114.5, 76.6, 32.2, 23.4, 9.9, 0.5. HRMS: calcd for $\mathrm{C}_{40} \mathrm{H}_{50} \mathrm{O}_{6} \mathrm{Si}_{2} \mathrm{Br}_{2}+\mathrm{NH}_{4}^{+}$, 858.1856; found, 858.1888.

Cone 5,17-dibromo-11,23,25,26,27,28-hexapropoxycalix[4]arene $\left(7 b_{1}\right)$. Following the general procedure for synthesis of alkoxy-calix[n]arene; compound $\mathbf{4 b}(670$ $\mathrm{mg}, 0.96 \mathrm{mmol}), \mathrm{NaH}(207 \mathrm{mg}, 8.63 \mathrm{mmol}), 1$-bromopropane $(0.79 \mathrm{ml}, 8.63 \mathrm{mmol})$ and DMF $(9 \mathrm{ml})$ were used. Recrystallization from solvent mixture $\mathrm{CHCl}_{3}$ $\mathrm{MeOH}$ yielded colorless crystalline product $(676 \mathrm{mg}$, $81 \%$ yield). IR (KBr): 2962, 2924, 2874, 1597, 1461, $1212 \mathrm{~cm}^{-1}$. ${ }^{1} \mathrm{H}$ NMR $\left(300 \mathrm{MHz}, \mathrm{CDCl}_{3}\right): \Delta 6.67(\mathrm{~s}, 4 \mathrm{H})$, $6.36(\mathrm{~s}, 4 \mathrm{H}), 4.37(\mathrm{~d}, J=13.2 \mathrm{~Hz}, 4 \mathrm{H}), 3.84-3.72(\mathrm{~m}$, $12 \mathrm{H}), 3.05(\mathrm{~d}, J=13.2 \mathrm{~Hz}, 4 \mathrm{H}), 1.93-1.84(\mathrm{~m}, 8 \mathrm{H}), 1.75$ $(\mathrm{m}, 4 \mathrm{H}), 1.05-0.92(\mathrm{~m}, 18 \mathrm{H}) .{ }^{13} \mathrm{C}$ NMR $(75.5 \mathrm{MHz}$, $\left.\mathrm{CDCl}_{3}\right): \Delta 155.7,154.3,151.0,136.9,136.0,130.9$, 115.3, 114.8, 70.1, 31.6, 23.7, 23.4, 23.1, 11.0, 10.9, 10.6. HRMS: calcd for $\mathrm{C}_{46} \mathrm{H}_{58} \mathrm{O}_{6} \mathrm{Br}_{2}+\mathrm{Na}^{+}$, 887.2498; found, 887.2515.

Partial-cone 5,17-dibromo-11,26,23,28-tetramethoxy-25,27-dipropoxycalix[4]arene $\left(7 b_{2}\right)$. Following slightly modified (as a solvent mixture of THF - DMF was used) general procedure for synthesis of alkoxy-calix[n]arene; compound $\mathbf{4 b}(158 \mathrm{mg}, 0.23 \mathrm{mmol}), \mathrm{NaH}$ ( $87 \mathrm{mg}, 3.62 \mathrm{mmol})$, MeI (0.31 ml, $4.98 \mathrm{mmol})$, THF (5 $\mathrm{ml})$, and DMF $(0.5 \mathrm{ml})$ were used. Recrystallization from solvent mixture $\mathrm{CH}_{2} \mathrm{Cl}_{2}-\mathrm{MeOH}$ yielded colorless crystalline product $(150 \mathrm{mg}, 88 \%$ yield). IR ( $\mathrm{KBr})$ : 2964, 2925, 2872, 1595, 1464, $1212 \mathrm{~cm}^{-1}$. ${ }^{1} \mathrm{H}$ NMR (300 $\left.\mathrm{MHz}, \mathrm{CDCl}_{3}\right): \Delta 7.09-6.44(\mathrm{~m}, 8 \mathrm{H}) 4.31-2.99(\mathrm{~m}, 24 \mathrm{H})$, 1.91-1.84 (m, 4H), 1.16-1.05 (m, 6H). ${ }^{13} \mathrm{C}$ NMR $(75.5$ $\left.\mathrm{MHz}, \mathrm{CDCl}_{3}\right): \Delta 155.8,155.3,155.2,155.0,154.2$, $152.9,152.5,152.0,137.2,136.0,135.8,134.0,133.8$, $132.1,130.8,130.3,116.5,115.5,115.0,114.5,114.3$, $76.4,61.3,60.2,59.7,55.9,55.8,36.0,31.2,24.3,24.1$, 11.3, 11.2. HRMS: calcd for $\mathrm{C}_{38} \mathrm{H}_{42} \mathrm{O}_{6} \mathrm{Br}_{2}+\mathrm{H}^{+}$, 753.1426; found, 753.1448 .

Partial-cone 5,17-bis(thioacetyl)-11,26,23,28-tetramethoxy-25,27-dipropoxycalix[4]arene (8). Following previously published method ${ }^{21}$ compound $7 \mathbf{b}_{\mathbf{2}}(100 \mathrm{mg}, 0.14$ $\mathrm{mmol})$, THF $(12 \mathrm{ml})$, tert $\mathrm{BuLi}(0.51 \mathrm{ml}, 1.46 \mathrm{M}$ in pentane, $0.86 \mathrm{mmol})$, sulfur $(28 \mathrm{mg}, 0.86 \mathrm{mmol})$ and $\mathrm{AcCl}(0.1$ $\mathrm{ml}, 1.44 \mathrm{mmol}$ ) were used. Column chromatography (EtOAc : $n$-hexane $1: 5$ ) yielded white powder product (25 mg, 25\% yield). IR (KBr): 2959, 2928, 2874, 2834, 1697, 1601, 1477, 1457, 1234, $1207 \mathrm{~cm}^{-1} .{ }^{1} \mathrm{H}$ NMR (300 $\left.\mathrm{MHz}, \mathrm{CDCl}_{3}\right): \Delta 7.00-6.36(\mathrm{~m}, 8 \mathrm{H}), 4.34-3.04(\mathrm{~m}, 24 \mathrm{H})$, $2.25(\mathrm{~s}, 3 \mathrm{H}), 2.13(\mathrm{~s}, 3 \mathrm{H}), 1.89(\mathrm{~m}, 4 \mathrm{H}), 1.05(\mathrm{~m}, 6 \mathrm{H}) .{ }^{13} \mathrm{C}$ NMR $\left(75.5 \mathrm{MHz}, \mathrm{CDCl}_{3}\right): \Delta 196.1,156.1,137.2,135.4$, 134.8, 134.4, 133.8, 116.4, 114.2, 114.0, 76.2, 61.2, 31.0, 30.2, 24.2, 11.1. HRMS: calcd for $\mathrm{C}_{42} \mathrm{H}_{48} \mathrm{O}_{8} \mathrm{~S}_{2}+\mathrm{H}^{+}$, 745.2869; found, 745.2878.

Cone 5,17-dibromo-26,28-bis(phenylmethoxy)-25,27dihydroxycalix[4]arene (9a). Compound 1a (3.9 g, 6.45 $\mathrm{mmol})$ was dissolved in $\mathrm{CHCl}_{3}(130 \mathrm{ml})$ and $\mathrm{Br}_{2}(0.66 \mathrm{ml}$, $12.96 \mathrm{mmol})$ solution in $\mathrm{CHCl}_{3}(130 \mathrm{ml})$ was slowly added in $2 \mathrm{~h}$ at $0{ }^{\circ} \mathrm{C}$. The reaction mixture was let to warm up to room temperature and stirred for additional $2 \mathrm{~h}$. The solvent was then removed under reduced pressure and remaining solid recrystallized. Recrystallization from solvent mixture $\mathrm{CHCl}_{3}-\mathrm{MeOH}$ yielded colorless crystalline product $\left(4.65 \mathrm{~g}, 95 \%\right.$ yield). ${ }^{1} \mathrm{H}$ NMR $\left(300 \mathrm{MHz}, \mathrm{CDCl}_{3}\right)$ : $\Delta 7.86(\mathrm{~s}, 2 \mathrm{H}), 7.61-6.80(\mathrm{~m}, 22 \mathrm{H}), 5.03(\mathrm{~s}, 4 \mathrm{H}), 4.23(\mathrm{~d}$, $J=13.2 \mathrm{~Hz}, 4 \mathrm{H}), 3.27(\mathrm{~d}, J=13.2 \mathrm{~Hz}, 4 \mathrm{H})$. The spectrum is in accordance with previously published results. ${ }^{36}$

Cone 5,17-dibromo-26,28-bis(phenylmethoxy)-25,27dipropoxycalix[4]arene $\left(\mathbf{1 0 a}_{1}\right)$. Following the general procedure for synthesis of alkoxy-calix[n]arene; compound 9a $(4.91 \mathrm{~g}, 6.45 \mathrm{mmol}), \mathrm{NaH}(541 \mathrm{mg}, 22.56$ $\mathrm{mmol}$ ), 1-bromopropane (2.05 $\mathrm{ml}, 22.56 \mathrm{mmol}$ ) and DMF $(60 \mathrm{ml})$ were used. Recrystallization from solvent mixture $\mathrm{CH}_{2} \mathrm{Cl}_{2}-\mathrm{MeOH}$ yielded colorless crystalline product $\left(5.01 \mathrm{~g}, 92 \%\right.$ yield). ${ }^{1} \mathrm{H}$ NMR $\left(300 \mathrm{MHz}, \mathrm{CDCl}_{3}\right): \Delta$ 7.42-7.32 (m, 10H), $7.02(\mathrm{~s}, 4 \mathrm{H}), 6.47-6.38(\mathrm{~m}, 6 \mathrm{H}), 4.82$ (s, 4H), $4.33(\mathrm{~d}, J=13.3 \mathrm{~Hz}, 4 \mathrm{H}), 3.74(\mathrm{~m}, 4 \mathrm{H}), 3.04(\mathrm{~d}, J$ $=13.3 \mathrm{~Hz}, 4 \mathrm{H}), 1.65(\mathrm{~m}, 4 \mathrm{H}), 0.64(\mathrm{t}, J=7.4 \mathrm{~Hz}, 6 \mathrm{H})$. The spectrum is in accordance with previously published results. ${ }^{37}$

Cone 5,17-bis(thioacetyl)-26,28-bis(phenylmethoxy)25,27-dipropoxycalix[4]arene (11a $)$. Following slightly modified ( $\mathrm{AcCl}$ was replaced by $\mathrm{MeI}$ ) previously published method; ${ }^{21}$ compound 10a 1 ( $\left.\mathrm{g}, 2.36 \mathrm{mmol}\right)$, THF (96 $\mathrm{ml})$, tert-BuLi $(16.67 \mathrm{ml}, 1,46 \mathrm{M}$ solution in pentane, $28.34 \mathrm{mmol})$, sulfur (1.06 g, $33.07 \mathrm{mmol})$ and MeI (2.35 $\mathrm{ml}, 37.79 \mathrm{mmol}$ ) were used. Column chromatography $\left(\mathrm{CH}_{2} \mathrm{Cl}_{2}: n\right.$-hexane $\left.2: 3\right)$ and recrystallization from solvent mixture $\left(\mathrm{CHCl}_{3}-\mathrm{MeOH}\right)$ yielded colorless crystalline product $(780 \mathrm{mg}, 42 \%$ yield). IR ( $\mathrm{KBr}): 3024,2961$, 2917, 2871, 1582, 1456, 1372, 1212, $1195 \mathrm{~cm}^{-1} .{ }^{1} \mathrm{H}$ NMR $\left(300 \mathrm{MHz}, \mathrm{CDCl}_{3}\right): \Delta$ 7.46-7.43 (m, 4H), 7.35-7.32 (m, $6 \mathrm{H}), 6.92(\mathrm{~s}, 4 \mathrm{H}), 6.37-6.29(\mathrm{~m}, 6 \mathrm{H}), 4.78(\mathrm{~s}, 4 \mathrm{H}), 4.38$ $(\mathrm{d}, J=13.2 \mathrm{~Hz}, 4 \mathrm{H}), 3.76(\mathrm{~m}, 4 \mathrm{H}), 3.07(\mathrm{~d}, J=13.2 \mathrm{~Hz}$, 4H), 2.44 (s, 6H), $1.64(\mathrm{~m}, 4 \mathrm{H}), 0.60(\mathrm{t}, J=7,4 \mathrm{~Hz}, 6 \mathrm{H})$. ${ }^{13} \mathrm{C}$ NMR $\left(75.5 \mathrm{MHz}, \mathrm{CDCl}_{3}\right): \Delta 155.9,154.7,137.6$, 137.0, 133.4, 130.0, 129.1, 128.2, 128.0, 127.9, 127.8, 122.5, 76.6, 31.1, 22.8, 17.3, 9.5. HRMS: calcd for $\mathrm{C}_{50} \mathrm{H}_{52} \mathrm{O}_{4} \mathrm{~S}_{2}+\mathrm{H}^{+}$, 781.3385; found, 781.3378.

Cone 5,17-bis(thioacetyl)-26,28-dihydroxy-25,27-dipropoxycalix[4]arene (12a $\mathbf{a}_{1}$ ). Compound $\mathbf{1 1 a}_{1}$ (89 $\mathrm{mg}$, 
$0.11 \mathrm{mmol})$ was dissolved in $\mathrm{CH}_{2} \mathrm{Cl}_{2}(15 \mathrm{ml})$ and molecular sieves were added. Mixture was cooled down to $-30{ }^{\circ} \mathrm{C}$ and trimethylsilyl bromide (TMSBr) $(0.12 \mathrm{ml}$, $0.91 \mathrm{mmol}$ ) was added and let to stir for $3 \mathrm{~h}$. Reaction mixture was then poured into saturated aqueous $\mathrm{Na}$ $\mathrm{HCO}_{3}$ solution and organic phase was separated. The organic phase was then extracted with $\mathrm{H}_{2} \mathrm{O}$ and dried with $\mathrm{MgSO}_{4}$. Solvents were removed under reduced pressure and crude product purified by column chromatography $\left(\mathrm{CH}_{2} \mathrm{Cl}_{2}:\right.$ n-hexane $\left.1: 1\right)$ followed by recrystallization from solvent mixture $\left(\mathrm{CHCl}_{3}-\mathrm{MeOH}\right)$ to yield colorless crystalline product (31 mg, $45 \%$ yield). IR ( $\mathrm{KBr}): 3330$, 2959, 2921, 2862, 1583,1464, 1436, $1203 \mathrm{~cm}^{-1} .{ }^{1} \mathrm{H}$ NMR (300 MHz, $\left.\mathrm{CDCl}_{3}\right): \Delta 8.33(\mathrm{~s}, 2 \mathrm{H}), 7.02(\mathrm{~d}, J=7.5$ $\mathrm{Hz}, 4 \mathrm{H}), 6.84(\mathrm{~s}, 4 \mathrm{H}), 6.62(\mathrm{t}, J=7.5 \mathrm{~Hz}, 2 \mathrm{H}), 4.28(\mathrm{~d}, J$ $=12.9 \mathrm{~Hz}, 4 \mathrm{H}), 3.95(\mathrm{t}, J=6.2 \mathrm{~Hz}, 4 \mathrm{H}), 3.34(\mathrm{~d}, J=12.9$ $\mathrm{Hz}, 4 \mathrm{H}), 2.31(\mathrm{~s}, 6 \mathrm{H}), 2.05(\mathrm{~m}, 4 \mathrm{H}), 1.31(\mathrm{t}, J=7.4 \mathrm{~Hz}$, $6 \mathrm{H}) .{ }^{13} \mathrm{C}$ NMR $\left(75.5 \mathrm{MHz}, \mathrm{CDCl}_{3}\right): \Delta 153.4,150.0$, 134.1, 133.6, 128.6, 127.7, 127.5, 119.2, 78.5, 31.5, 23.5, 16.2, 10.9. HRMS: calcd for $\mathrm{C}_{36} \mathrm{H}_{40} \mathrm{O}_{4} \mathrm{~S}_{2}+\mathrm{H}^{+}$, 601.2446; found, 601.2451.

Cone 11,26,23,28-tetraone-25,27-bis-[(hydroxycarbonyl)methoxy]-calix[4]arene (13). To a solution of 2c (190 mg, $0.28 \mathrm{mmol})$ in $\mathrm{CH}_{2} \mathrm{Cl}_{2}(3 \mathrm{ml})$, trifluoroacetic acid $(0.6 \mathrm{ml}, 7.53 \mathrm{mmol})$ was slowly added and then let to stir at room temperature under inert atmosphere for $5 \mathrm{~h}$. Reaction was quenched by addition of cold $\mathrm{H}_{2} \mathrm{O}\left(0{ }^{\circ} \mathrm{C}\right)$. Organic phase was separated from aqueous and dried with $\mathrm{MgSO}_{4}$. Solvent was concentrated under reduced pressure and product precipitated as a yellow crystalline substance (105 mg, 66\% yield). ${ }^{1} \mathrm{H}$ NMR (300 MHz, DMSO-d ${ }_{6}$, 2.50): $\Delta 6.83(\mathrm{~s}, 4 \mathrm{H}), 6.75(\mathrm{~d}, J=7.5 \mathrm{~Hz}, 4 \mathrm{H}), 6.64(\mathrm{t}, J=$ $7.5 \mathrm{~Hz}, 2 \mathrm{H}), 4.41(\mathrm{~s}, 4 \mathrm{H}), 3.83(\mathrm{~d}, J=13.1 \mathrm{~Hz}, 4 \mathrm{H}), 3.33$ $(\mathrm{d}, J=13.1 \mathrm{~Hz}, 4 \mathrm{H})$. The spectrum is in accordance with previously published results. ${ }^{25}$

Cone 11,26,23,28-tetrahydroxy-25,27-bis-[(hydroxycarbonyl)methoxy]-calix[4]arene (14). Compound 13 (50 $\mathrm{mg}, 0.09 \mathrm{mmol}$ ) was dissolved in MEK (4 ml) and aqueous solution of $\mathrm{Na}_{2} \mathrm{~S}_{2} \mathrm{O}_{4}(122 \mathrm{mg}, 0.70 \mathrm{mmol}$ in 2 $\mathrm{ml}$ of $\mathrm{H}_{2} \mathrm{O}$ ) was added. Yellow color of reaction mixture disappeared during stirring $(1 \mathrm{~min})$. Organic phase was separated from aqueous and dried with $\mathrm{MgSO}_{4}$. After addition of $\mathrm{CHCl}_{3}(5 \mathrm{ml})$ to the dried organic phase, a precipitate formed. This was filtered off using PTFE filter $(0.2 \mu \mathrm{m})$ and dried. The product was isolated as a pale yellow powder (18 mg, $36 \%$ yield). IR ( $\mathrm{KBr})$ : 3434 , 2932, 1739, 1609, 1464, 1440, 1242, $1193 \mathrm{~cm}^{-1} .{ }^{1} \mathrm{H}$ NMR (300 MHz, DMSO-d $\left.{ }_{6}, 2.50\right): \Delta 7.00(\mathrm{~d}, J=7.6 \mathrm{~Hz}$, $4 \mathrm{H}), 6.78(\mathrm{t}, J=7.6 \mathrm{~Hz}, 2 \mathrm{H}), 6.47(\mathrm{~s}, 4 \mathrm{H}), 4.68(\mathrm{~s}, 4 \mathrm{H})$, $4.36(\mathrm{~d}, J=12.8 \mathrm{~Hz}, 4 \mathrm{H}), 3.25(\mathrm{~d}, J=12.8 \mathrm{~Hz}, 4 \mathrm{H}) .{ }^{13} \mathrm{C}$ NMR (75.5 MHz, DMSO-d $\left.{ }_{6}, 39.52\right): \Delta$ 170.5, 153.1, $149.7,144.5,133.9,129.0,128.9,125.0,114.9,72.1$, 31.0. HRMS: calcd for $\mathrm{C}_{32} \mathrm{H}_{28} \mathrm{O}_{10}+\mathrm{Na}^{+}, 595.1580$; found, 595.1568.

\section{2. Preparation of $\mathrm{Au}(111)$ Substrate.}

$\mathrm{Au}(111)$ single crystal (MaTecK) was annealed in $\mathrm{UHV}$ at $550^{\circ} \mathrm{C}$ after ion bombardment with $1 \mathrm{kV} \mathrm{Ar}^{+}$ions at $5 \times 10^{-6}$ mbar. The cycle was repeated at least two times. Au(111) single crystal was then transferred to a homemade annealing apparatus and annealed at $700{ }^{\circ} \mathrm{C}$ in $3 \% \mathrm{H}_{2} / \mathrm{Ar}$ atmosphere for $30 \mathrm{~min}$. The surface of the $\mathrm{Au}(111)$ single crystal was protected with $\mathrm{H}_{2} \mathrm{O}$ droplet $(30 \mu \mathrm{L})$ and transferred to a vial for self-assembly.

\section{3. Self-assembly}

»Ex-situ« method. $\mathrm{Au}(111)$ was immersed into $\sim 80$ $\mu \mathrm{M}$ solution (solvent mixture $\mathrm{CH}_{2} \mathrm{Cl}_{2}$ : EtOH $1: 9$ ) of adsorbate molecules $\mathbf{2 f}$ and $\mathbf{2 g}$ at room temperature for 30 min. Adsorbate solutions; were always freshly prepared. After self-assembly the $\mathrm{Au}(111)$ was removed from the solution and washed with EtOH, i-PrOH in Milli-Q $\mathrm{H}_{2} \mathrm{O}$, and dried in Ar atmosphere.

»In-situ « method. The surface of $\mathrm{Au}(111)$ single crystal was immersed into an electrochemical cell with $0.1 \mathrm{M} \mathrm{HClO}_{4}$ with $\sim 80 \mu \mathrm{M}$ concentrations of $\mathbf{1 3}$ and $\mathbf{1 4}$. The system was hold at $0.2 \mathrm{~V}$ vs $\mathrm{Ag} / \mathrm{AgCl}$ for $10 \mathrm{~min}$.

\section{4. Electrochemistry}

A standard three-compartment electrochemical cell containing $0.1 \mathrm{M} \mathrm{HClO}_{4}$ (OmniTrace Ultra ${ }^{\mathrm{TM}}$ from $\mathrm{EDM}), \mathrm{Au}$ wire as a counter electrode and $\mathrm{Ag} / \mathrm{AgCl}$ as a reference electrode was used. In each experiment, the electrode was immersed (hanging meniscus technique) at $0.07 \mathrm{~V}$ in a solution saturated with Ar and cycled between $0.07 \mathrm{~V}$ and $1.17 \mathrm{~V}$ versus the reversible hydrogen electrode (RHE). The sweep rate for all measurements was 50 $\mathrm{mVs}^{-1}$. Electrode potentials are given versus the RHE. Autolab potentiostat was used in the electrochemical measurements.

\section{Acknowledgements}

I thank to Ministry of Higher Education, Science and Technology of Slovenia (ARRS-3311-04-831034) and AdFutura for financial support, Dr. Dušan Strmčnik for help with electrochemical measurements, Dr. Bogdan Kralj for HRMS measurements and Prof. Dr. Slovenko Polanc for fruitful discussions about organic synthesis.

\section{References}

1. Yang, Z.; Zhang, J.; Kintner-Meyer, M. C. W.; Lu, X.; Choi, D.; Lemmon, J. P.; Liu, J. Chem. Rev. 2011, 111, 3577-3613 http://dx.doi.org/10.1021/cr100290v.

2. Goodenough, J. B.; Park, K. S. J. Am. Chem. Soc. 2013, 135, 1167-1176. http://dx.doi.org/10.1021/ja3091438 
3. Noorden, R. Van Nature 2014, 507, 26-28. http://dx.doi.org/10.1038/507026a

4. Chen, Z.; Qin, Y.; Amine, K. Electrochim. Acta 2009, 54, 5605-5613. http://dx.doi.org/10.1016/j.electacta.2009.05.017

5. Song, Z.; Zhou, H. Energy Environ. Sci. 2013, 6, 2280. http://dx.doi.org/10.1039/c3ee40709h

6. Liang, Y.; Tao, Z.; Chen, J. Adv. Energy Mater. 2012, 2, 742-769. http://dx.doi.org/10.1002/aenm.201100795

7. Sevov, C. S.; Brooner, R. E. M.; Chénard, E.; Assary, R. S.; Moore, J. S.; Rodríguez-López, J.; Sanford, M. S. J. Am. Chem. Soc. 2015, 4, jacs.5b09572.

8. Huang, Y.; Gu, S.; Yan, Y.; Li, S. F. Y. Curr. Opin. Chem. Eng. 2015, 8, 105-113. http://dx.doi.org/10.1016/j.coche.2015.04.001

9. Pan, F.; Wang, Q. Molecules 2015, 20, 20499-20517. http://dx.doi.org/10.3390/molecules201119711

10. Genorio, B.; Pirnat, K.; Cerc-Korosec, R.; Dominko, R.; Gaberscek, M. Angew. Chem. Int. Ed. 2010, 49, 7222-7224. http://dx.doi.org/10.1002/anie.201001539

11. Pirnat, K.; Dominko, R.; Cerc-Korosec, R.; Mali, G.; Genorio, B.; Gaberscek, M. J. Power Sources 2012, 199, 308-314. http://dx.doi.org/10.1016/j.jpowsour.2011.10.068

12. Pirnat, K.; Bitenc, J.; Jerman, I.; Dominko, R.; Genorio, B. ChemElectroChem 2014, 1, 2131-2137. http://dx.doi.org/10.1002/celc.201402234

13. Genorio, B. Acta Chim. Slov. 2015, 62, 895-901. http://dx.doi.org/10.17344/acsi.2015.1626

14. Chen, H.; Armand, M.; Demailly, G.; Dolhem, F.; Poizot, P.; Tarascon, J.-M. ChemSusChem 2008, 1, 348-355. http://dx.doi.org/10.1002/cssc.200700161

15. Liu, M.; Visco, S. J.; De Jonghe, L. C. J. Electrochem. Soc. 1989, 136, 2570-2575. http://dx.doi.org/10.1149/1.2097478

16. Nakahara, K.; Oyaizu, K.; Nishide, H. Chem. Lett. 2011, 40, 222-227. http://dx.doi.org/10.1246/cl.2011.222

17. Häupler, B.; Wild, A.; Schubert, U. S. Adv. Energy Mater. 2015, 5, 1402034-1402068. http://dx.doi.org/10.1002/aenm.201402034

18. Wain, A. J.; Wildgoose, G. G.; Heald, C. G. R.; Jiang, L.; Jones, T. G. J.; Compton, R. G. J. Phys. Chem. B 2005, 109, 3971-3978. http://dx.doi.org/10.1021/jp040552u

19. Wang, W.; Xu, W.; Cosimbescu, L.; Choi, D.; Li, L.; Yang, Z. Chem. Commun. 2012, 48, 6669. http://dx.doi.org/10.1039/c2cc32466k

20. Gutsche, C. D. Calixarenes; Stoddard, J. F., Ed.; Monographs in Supramolecular Chemistry; 2nd ed.; The Royal Society of Chemistry: Cambridge, 2008.

21. Genorio, B.; He, T.; Meden, A.; Polanc, S.; Jamnik, J.; Tour, J. M. Langmuir 2008, 24, 11523-11532. http://dx.doi.org/10.1021/la802197u
22. Genorio, B.; Strmcnik, D.; Subbaraman, R.; Tripkovic, D.; Karapetrov, G.; Stamenkovic, V. R.; Pejovnik, S.; Marković, N. M. Nat. Mater. 2010, 9, 998-1003. http://dx.doi.org/10.1038/nmat2883

23. Genorio, B.; Subbaraman, R.; Strmenik, D.; Tripkovic, D.; Stamenkovic, V. R.; Markovic, N. M. Angew. Chem. Int. Ed. 2011, 50, 5468-72. http://dx.doi.org/10.1002/anie.201100744

24. Love, J. C.; Estroff, L. a.; Kriebel, J. K.; Nuzzo, R. G.; Whitesides, G. M. Self-assembled monolayers of thiolates on metals as a form of nanotechnology; 2005; Vol. 105.

25. Chung, T. D.; Park, J.; Kim, J.; Lim, H.; Choi, M. J.; Kim, J. R.; Chang, S. K.; Kim, H. Anal. Chem. 2001, 73, 3975-80. http://dx.doi.org/10.1021/ac001050p

26. Takiguchi, H.; Sato, K.; Ishida, T.; Abe, K.; Yase, K.; Tamada, K. Langmuir 2000, 16, 1703-1710. http://dx.doi.org/10.1021/la981450w

27. Jadhav, S. a. Cent. Eur. J. Chem. 2011, 9, 369-378. http://dx.doi.org/10.2478/s11532-011-0024-8

28. Han, S. W.; Joo, S. W.; Ha, T. H.; Kim, Y.; Kim, K. J. Phys. Chem. B 2000, 104, 11987-11995. http://dx.doi.org/10.1021/jp002630t

29. Casnati, A.; Comelli, E.; Fabbi, M.; Bocchi, V.; Mori, G.; Ugozzoli, F.; Lanfredi, A. M. M.; Pochini, A.; Ungaro, R. Recl. des Trav. Chim. des Pays-Bas 1993, 112, 384-392. http://dx.doi.org/10.1002/recl.19931120613

30. Kim, Y.-O.; Jung, Y. M.; Kim, S. Bin; Hong, B. H.; Kim, K. S.; Park, S.-M. J. Phys. Chem. B 2004, 108, 4927-4936. http://dx.doi.org/10.1021/jp049864n

31. Gutsche, C. D.; Lin, L.-G. Tetrahedron 1986, 42, 16331640. http://dx.doi.org/10.1016/S0040-4020(01)87580-3

32. van Loon, J.-D.; Arduini, A.; Coppi, L.; Verboom, W.; Pochini, A.; Ungaro, R.; Harkema, S.; Reinhoudt, D. N. J. Org. Chem. 1990, 55, 5639-5646.

http://dx.doi.org/10.1021/jo00308a024

33. Arduini, A.; Fabbi, M.; Mantovani, M.; Mirone, L.; Pochini, A.; Secchi, A.; Ungaro, R. J. Org. Chem. 1995, 60, 14541457. http://dx.doi.org/10.1021/jo00110a055

34. Zeng, X.; Sun, H.; Chen, L.; Leng, X.; Xu, F.; Li, Q.; He, X.; Zhang, W.; Zhang, Z. Z. Org. Biomol. Chem. 2003, 1, 10731079. http://dx.doi.org/10.1039/b211381c

35. Lin, Y. L.; Yu, T. S.; Wang, W. Y.; Lin, L. G. Tetrahedron 2006, 62, 6082-6089.

http://dx.doi.org/10.1016/j.tet.2006.03.110

36. Shimizu, S.; Shirakawa, S.; Sasaki, Y.; Hirai, C. Angew. Chemie - Int. Ed. 2000, 39, 1256-1259.

http://dx.doi.org/10.1002/(SICI)1521-3773(20000403)39:7 $<1256:$ :AID-ANIE1256>3.0.CO;2-F

37. Lai, S.; Chan, Q. K.-W.; Han, J.; Zhi, Y.; Zhu, N.; Che, C. Organometallics 2009, 28, 34-37.

http://dx.doi.org/10.1021/om800969z 


\section{Povzetek}

Opisana je sinteza in karakterizacija novih elektroaktivnih dikinonskih in kinonskih derivatov kaliks[4]arena s sidrnimi funkcionalinimi skupinami. Razvita je bila tudi metoda selektivne zaščite hidrokinonskih -OH skupin s trimetilsililnimi skupinami (TMS) na spodnjem oz. zgornjem obroču makrocikla. Štiri molekule, s sulfidnimi oz. s karboksilnimi sidri so bile adsorbirane na površino monokristala $\mathrm{Au}(111)$, z uporabo ex-situ in in-situ metode samosestavljivosti. Adsorbirane molekule smo testirali s ciklično voltametrijo (CV). Vse testirane molekule so pokazale redox odziv, ki se je spreminjal med posameznimi cikli. Po kondicioniranju so se CV-ji ustalili in pokazali dva izrazita tokovna vrhova, podobna za vse testirane molekule. Sintetizirane in elektrokemijsko testirane molekule so zanimive za: Li-ionske baterije (kot katodni material oz. kot zaščita prenapetosti), baterije $\mathrm{z}$ novimi kemijami in redoks-pretočne baterije. 